Article

\title{
Evaluation of the Economic, Environmental, and Social Impacts of the COVID-19 Pandemic on the Japanese Tourism Industry
}

\author{
Yusuke Kitamura ${ }^{1, * \mathbb{D}}$, Selim Karkour ${ }^{1}$, Yuki Ichisugi ${ }^{2}$ and Norihiro Itsubo ${ }^{1}$ \\ 1 Graduate School of Environmental and Information Studies, Tokyo City University, \\ Yokohama 224-8551, Japan; g1893103@tcu.ac.jp (S.K.); itsubo-n@tcu.ac.jp (N.I.) \\ 2 Research Institute of Science for Safety and Sustainability, National Institute of Advanced Industrial Science \\ and Technology, Tsukuba 305-8569, Japan; y0110.ichisugi@aist.go.jp \\ * Correspondence: g1893104@tcu.ac.jp; Tel.: +81-45-910-2930
}

Received: 8 November 2020; Accepted: 6 December 2020; Published: 9 December 2020

check for updates

\begin{abstract}
According to the United Nations Environment Program (UNEP) annual Emissions Gap Report 2019, further reductions in greenhouse gas (GHG) emissions are needed to reduce climate change impacts. In Japan, the 2030 Intended Nationally Determined Contribution (INDC) target is an emissions reduction of $26 \%$ compared to 2013. The World Health Organization (WHO) declared that the coronavirus (COVID-19) outbreak has led to 43,341,451 confirmed cases and 1,157,509 confirmed deaths globally and affected 218 countries (as of 27 October 2020). In Japan, as of the same date, 96,948 infectious cases and 1724 deaths related to the new coronavirus had been recorded. These numbers continue to increase. In Japan, in March 2020, the number of international tourist arrivals decreased by about $93 \%$ compared to last year at the same period. The World Tourism Organization (UNWTO) reported several significant scenarios for the tourism industry. COVID-19 is the greatest shock to international tourism since 1950 and represents an abrupt end to the 10-year period of sustained growth that followed the 2009 financial crisis. It was thought that it would be possible to analyze the economic, environmental, and social impacts of rapid social changes. Thus, this study estimates changes in Japan's tourist consumption, the carbon footprint (CFP), and employment due to the influence of the COVID-19 pandemic. The calculations in this study adopt a lifecycle approach using input-output tables. Based on these observations, this study uses four scenarios (SR 1, no recovery until December; SR 2, recovery from October; SR 3, recovery from July or September; and SR 0, same growth rate as 2018-2019) for Japan to calculate the CFP and employment change using input-output table analysis based on tourist consumption, which is a tourism metric. According to our results (2019 vs. SR 1 and 3), the consumption loss is between 20,540 billion yen $(-65.1 \%)$ and 12,704 billion yen $(-39.1 \%)$, the CFP reduction is between $89,488 \mathrm{kt}-\mathrm{CO}_{2} \mathrm{eq}(-64.2 \%)$ and $54,030 \mathrm{kt}-\mathrm{CO}_{2} \mathrm{eq}(-37.5 \%)$, and the employment loss is between $2,677,000$ people $(-64.2 \%)$ and $1,678,000$ people $(-37.5 \%)$. As of November 2020 , the tourism industry continues to be affected by the COVID-19 pandemic. In the post-COVID-19 society, it will be necessary to maintain the GHG emissions reductions achieved in this short period and realize economic recovery. This recovery must also be sustainable for tourism stakeholders and society.
\end{abstract}

Keywords: life cycle assessment (LCA); carbon footprint (CFP); economic, environmental, and social analysis; sustainable tourism; coronavirus (COVID-19) pandemic

\section{Introduction}

The Paris Agreement was adopted in 2015 with the agreement of 195 countries of the United Nations (UN) [1]. The United Nations Environment Program (UNEP) annual Emissions Gap Report 
2019 predicted that global emissions must be reduced by $7.6 \%$ each year in coming decades to meet the $1.5^{\circ} \mathrm{C}$ Paris target [2]. In Japan, the 2030 Intended Nationally Determined Contribution (INDC) target is for an emissions reduction of $26 \%$ compared to 2013 [3]. Furthermore, Japan's Long-term Strategy under the Paris Agreement announced that it will aim to reduce emissions by $80 \%$ by 2050 [4]. On 26 October 2020, the Government of Japan declared that greenhouse gas (GHG) emissions in Japan will be cut to net-zero by 2050 [5].

The World Health Organization (WHO) declared the coronavirus (COVID-19) a pandemic on 11 March 2020. This pandemic is an unprecedented global challenge affecting all communities and economies [6]. According to the WHO, the COVID-19 outbreak has led to 43,341,451 confirmed cases and 1,157,509 confirmed deaths, affecting 218 countries (as of 27 October 2020) [7]. In Japan, as of the same date, 96,948 infectious cases and 1724 deaths related to the new coronavirus had been recorded [8]. These numbers continue to increase.

The Japanese government announced a state of emergency from 7 April to 31 May 2020. Under this declaration, people were restricted from going out and encouraged "stay home", and many stores were forced to close [9]. This basic coping policy required self-restraint to reduce unnecessary homecomings and travel across prefectures [10]. This had economic impacts on numerous domestic industries, including the tourism industry. Kuniya, T. (2020) estimated that the tourist peak in Japan is around early summer [11]. There is a concern that the longer the impact of the pandemic, the greater the effect on the economy.

According to the International Monetary Fund (IMF) [12], global growth is projected to be $-3.0 \%$ in 2020, an outcome considerably worse than that during the 2009 global financial crisis. For Japan, real Gross Domestic Product (GDP) growth in 2020 is forecast to be $-5.2 \%$. The World Tourism Organization (UNWTO) stated that the worldwide outbreak of COVID-19 has had a major impact on the global economy, with tourism one of the worst affected of the major sectors. Against a backdrop of heightened uncertainty, up-to-date and reliable information is increasingly important, both for tourists and for the tourism sector [13]. In Japan, the number of international tourist arrivals decreased by about 93\% (March 2020) [14]. According to the Japan Tourism Agency (JTA), inbound tourist consumption, according to national survey results for the January-March period of 2020 (first preliminary report), decreased $41.6 \%$ from the same period last year [15]. The overnight travel statistics survey showed a decrease of $49.6 \%$ (March 2020) compared with the same month last year. In particular, the total number of foreign guests fell $85.9 \%$ due to a decrease in inbound tourism [16]. In Japan, the tourism industry has been affected by the continued impact of COVID-19. It is clear that the tourism industry will continue to be affected, but the final magnitude of this impact remains unclear.

The report of the UNWTO [17], updated in May 2020, detailed (as of 20 April) all of the COVID-19-related travel restrictions for all global destinations introduced in response to the pandemic. Currently projected scenarios point to declines of $58 \%$ to $78 \%$ in international tourist arrivals for 2020, depending on the speed of the containment, the duration of travel restrictions, and the shutdown of international borders, although the outlook remains highly uncertain. These scenarios would put 100 to 120 million direct tourism jobs at risk.

Nicola et al. (2020) [18] showed that hospitality and tourism are most likely the hardest hit sectors. Mariolis et al. (2020) [19] predicted the impact of COVID-19 on GDP, total employment, and the trade balance in Greece. They found that the main effect was on the revenue of "hotel and restaurant services". Sun et al. (2020) [20] showed a significant decline in global aviation connections. Chang et al. (2020) [21] noted the importance of resuming tourism activities to maximize economic, social, and environmental contributions to turn future crises into sustainability opportunities.

Lenzen et al. (2018) [22] calculated the carbon footprint (CFP) of global tourism using an input-output life cycle assessment (LCA). CFP evaluation using this method has been applied in case studies in USA [23], New Zealand [24], UK [25], The Netherlands [26], Spain [27], China [28], and Japan [29]. Isaifan (2020) [30] showed that the outbreak of COVID-19 forced China to lockdown its industrial activities, and hence reduced its $\mathrm{NO}_{2}$ and carbon emissions by $30 \%$ and $25 \%$, respectively. 
However, Cooper et al. (2020) [31] noted that the economic impact of COVID-19 cancellations clearly shows that reducing GHG emissions is not the only goal of sustainable tourism. Finally, Sun et al. (2020) [32] proposed a comprehensive Tourism Carbon Information System (TCIS) consisting of four important information components. They found that information on the tourism CFP is rarely available to policy makers, because relevant information is not directly edited and tracked in a country's greenhouse gas statistics.

Japan's tourism industry is expected to experience an employment-related effect as part of a large and wider economic effect [33]. It is hoped that the recovery of tourism will overcome these challenges, including economic, social, and environmental issues, leading to sustainable tourism in the future. It is clear that the post-COVID-19 society requires meaningful consideration. It is also important to have an understanding of the potential for positive impact on environmental issues in a short period of time, and to quantify the importance of the CFP as an approach to climate change.

It was thought that it would be possible to analyze the economic, environmental, and social impacts of rapid social changes. The calculations in this study adopt a lifecycle approach using input-output tables. This study thus estimates changes in Japan's tourist consumption, CFP, and employment due to the influence of the COVID-19 pandemic.

\section{Materials and Methods}

\subsection{System Boundaries}

As shown in Table 1, the system boundaries of this study follow the traditional approach adopted for tourism evaluation. The different stages are Preparation (Pre-tourism), Inbound Tourism, Domestic Tourism, Outbound Tourism, and After (Post-tourism). These stages cover consumption related to the movement and accommodation of tourists and the staff and participants of MICE events. However, these do not include the consumption of foreign tourists before or after travelling or items purchased by MICE organizers or energy consumption at the venues.

Table 1. Scope of the evaluation data. The items evaluated in this study are displayed as " $\bigcirc$ ", and "N" indicates not applicable. " $\mathrm{P}$ " indicates preparing for travel, " $\mathrm{W}$ " indicates while traveling, and " $\mathrm{A}$ " indicates after travel. This target range is based on Kitamura et al. (2020) [29].

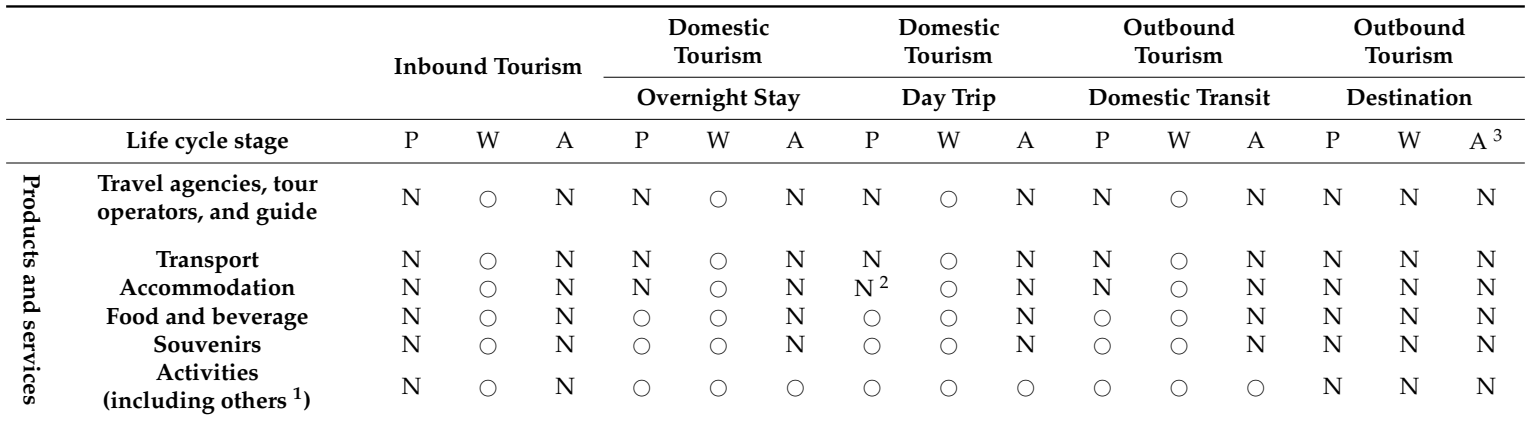

${ }^{1}$ This includes not only cultural services, recreation, and other entertainment services, but also other services.

2 Day trips are not included for non-staying trips. ${ }^{3}$ After is included in "transit" of domestic tourism.

The tourism statistics data, "Internal and national tourism consumption, by timing of purchase and products", provided by the JTA [34], distinguish between foreign visitors visiting Japan (referred to as inbound tourism in this study); domestic tourism, which also includes the travel within Japan of foreign visitors (e.g., flight connections); and the overseas travel of Japanese nationals and foreign residents (referred to in this study as outbound tourism). The items evaluated in this study are displayed as " $\bigcirc$ " in Table 1, and those that are not included are displayed as "not applicable". These data were provided in JPY (1\$ = 117 JPY (2017 Ave.)) [35]. Table 2 shows the target years and scenarios of this study. 
Table 2. Scenarios for each tourism type.

\begin{tabular}{|c|c|c|c|c|}
\hline Type of Tourism & Scenario 1 (SR 1) & Scenario 2 (SR 2) & Scenario 3 (SR 3) & Scenario 0 (SR 0) \\
\hline Inbound & $\begin{array}{l}\text { August levels } \\
\text { continue until } \\
\text { December }\end{array}$ & $\begin{array}{l}\text { August level continues until } \\
\text { September, and from October it } \\
\text { improves at the rate of } \\
\text { July to August }\end{array}$ & $\begin{array}{l}\text { From September, } \\
\text { the improvement rate } \\
\text { from July to August }\end{array}$ & $\begin{array}{l}2019-2020 \text { will have } \\
\text { the same growth rate } \\
\text { as 2018-2019 }\end{array}$ \\
\hline $\begin{array}{c}\text { Domestic } \\
\text { (Overnight stay) } \\
\text { Domestic (Day trip) }\end{array}$ & $\begin{array}{l}\text { June levels continue } \\
\text { until December }\end{array}$ & $\begin{array}{l}\text { June level continues until } \\
\text { September, and from October it } \\
\text { improves at the rate of } \\
\text { May to June }\end{array}$ & $\begin{array}{l}\text { From July, } \\
\text { the improvement rate } \\
\text { from May to June }\end{array}$ & $\begin{array}{l}2019-2020 \text { will have } \\
\text { the same growth rate } \\
\text { as 2018-2019 }\end{array}$ \\
\hline $\begin{array}{c}\text { Outbound } \\
\text { (Domestic transit) }\end{array}$ & $\begin{array}{l}\text { August levels } \\
\text { continue until } \\
\text { December }\end{array}$ & $\begin{array}{l}\text { August level continues until } \\
\text { September, and from October it } \\
\text { improves at the rate of } \\
\text { July to August. }\end{array}$ & $\begin{array}{l}\text { From September, } \\
\text { the improvement rate } \\
\text { from July to August }\end{array}$ & $\begin{array}{l}2019-2020 \text { will have } \\
\text { the same growth rate } \\
\text { as 2018-2019 }\end{array}$ \\
\hline $\begin{array}{l}\text { Outbound } \\
\text { (Destination) }\end{array}$ & $\mathrm{N}$ & $\mathrm{N}$ & $\mathrm{N}$ & $\mathrm{N}$ \\
\hline
\end{tabular}

\subsection{Calculation Method of Economic Analysis}

First, the calculation method used in the economic analysis is shown as follows:

$$
\sum_{k=1}^{4} T E C_{k}=E c_{i t}+E c_{d t(o)}+E c_{d t(d)}+E c_{o t}
$$

Statistical data for Tourism Economic Consumption (TEC) [34] were applied from 2011 to 2017 based on the Tourism Satellite Account (TSA). These data include spending on different types of travel, defined as " $k$ " (type of tourism), including economic consumption of inbound tourism ( $\left.E c_{i t}\right)$, economic consumption of domestic tourism for overnight stays $\left(E c_{d t(o)}\right)$, economic consumption of domestic tourism for day trips $\left(E c_{d t(d)}\right)$, and economic con sumption of outbound tourism $\left(E c_{o t}\right)$.

Next, we derived estimates for 2018e (estimate)-2020e (estimate). Statistical data for this period are not available. Based on the consumption data of 2017, we applied the actual growth rate of the past five years (2013 to 2017) to each type of tourism. These rates were $127 \%$ for inbound tourism, $101.7 \%$ for domestic tourism (overnight stay), $102.6 \%$ for domestic tourism (day trip), and $100.2 \%$ for overseas tourism (domestic transit). Outbound tourism (rate of 97.7\%) was not covered by this study.

Then, the amount of consumption per traveler was estimated. Finally, this was multiplied by the number of travelers per month to estimate the annual consumption for each year. The number of inbound and outbound tourists was provided by the Japan National Tourism Organization (JNTO) [36]. Domestic tourism (overnight stays and day trips) data was provided by JTA [37].

Evaluation scenarios of this study were divided into four types (Table 2). Scenario 1 (SR 1) maintains inbound and outbound (domestic transit) tourism at the August level until December, and domestic (overnight stay and day trip) tourism levels for June are maintained until December. In Scenario 2 (SR 2), inbound and outbound (domestic transit) tourism is maintained at the August level until September; from October, the level increases at the same rate as that of July until August. Domestic (overnight stay and day trip) tourism maintains the June level until September, and from October, it increases at the same rate as that of May until June. In Scenario 3 (SR 3), inbound and outbound (domestic transit) tourism increases from September at the same rate as that of July until August. Domestic (overnight stay and day trip) tourism increases from July at the same improvement rate as that of May until June. Finally, Scenario 0 (SR 0) assumes that 2019-2020 would have the same growth rate as that of 2018-2019. Evaluations were categorized according to these four scenarios.

For 2020, public statistics are available from January to August for inbound and outbound tourism, and from January to June for domestic (overnight stay and day trip) tourism. In addition, the per capita spending composition of tourists is the same as that of 2019 (based on the 2017 evaluation). Scenarios 1-3 do not include economic effects such as government strategic campaigns. In addition, Scenario 0 does not include the economic effects of Tokyo 2020. 


\subsection{Calculation Method of Environmental Analysis}

Second, in this study, input-output analysis, based on the Japanese input-output table, was adopted for calculation in each year. The principles of this method are based on the works from W.W. Leontief [38] and are often used in the LCA research field, in which $d$ is the direct environmental impact and the environmental impact per production value; $(I-A)^{-1}$ is the Leontief inverse matrix, which can be used to consider the direct and indirect economic ripple effects caused by the consumption of one type of good; $f$ is the amount of activity. This method helps to evaluate the entire supply chain. This study calculated the CFP using the input-output LCA. The calculation formula is shown below:

$$
\sum_{k=1}^{4} C F P_{k}=d_{i}(I-A)^{-1} f_{i}+D E_{i}
$$

where $d_{i}$ is the direct GHG emission intensity provided for each sector by the Inventory Database for Environmental Analysis version 2 (IDEAv.2), developed by the National Institute of Advanced Industrial Science and Technology (AIST) [39]. $A$ is the direct input coefficient matrix: we used the 2011 waste input-output table (WIO) developed by Kondo et al. (2019) [40] to provide a broad overview. I is an identity matrix, $(I-A)^{-1}$ is the Leontief inverse matrix, and $f_{i}$ is the activity level, obtained from the statistics of the JTA [34], as detailed previously. It would be more effective to use data focusing on the same year; however, the last waste input-output table available focuses only on 2011. $D E_{i}$ is the direct emissions from fuel combustion included in the calculation to cover the full cradle-to-grave aspects of products and services; that is, using this equation, the calculation was extended from cradle-to-gate to cradle-to-grave. Based on the results of Kitamura et al. (2020) [29], who applied these calculations to tourism, we compiled a list of GHG emissions of tourism products and services (Appendix A, Table A1). In addition, the evaluation scenarios used in environmental analysis were the same as those used for the economic analysis.

\subsection{Calculation Method of Social Analysis}

Third, we calculated the number of employees. Ichisugi et al. [41] developed an employment factor to evaluate social aspects from the Japanese input-output table. This employment factor was also adopted in the social evaluation of this study, and can be expressed as:

$$
\sum_{k=1}^{4} E M P_{k}=d_{i}(I-A)^{-1} f_{i}
$$

where $d_{i}$ is a direct factor and $(I-A)^{-1}$ is the Leontief inverse matrix. The direct factor per million yen was calculated by dividing the social evaluation data for each industrial sector by the value of domestic production. The employment factor was created by multiplying this by the Leontief inverse matrix. $f_{i}$ is the amount of activity obtained from the estimates of each TEC. The number of employees (EMP) was calculated by multiplying this employment factor by the amount of consumption of each type of tourism. We used three categories of employment: paid officer, permanent employer, and temporary employer. Then, these were added together to provide the number of employees (Appendix A, Table A1). In addition, the evaluation scenarios used in environmental analysis were the same as those used for the economic analysis.

\section{Results}

\subsection{Economic, Environmental, and Social Evaluation}

We show the results of the estimation in Table 3. In 2019, the economy (consumption) valued at $30,514.5$ billion yen, the environment (CFP) was $134,468.4 \mathrm{kt}-\mathrm{CO}_{2} \mathrm{eq}$, and the society (employment) was $3,955,200$ people. In 2020, Scenarios 1 to 3, estimated consumption ranged from 9974.2 to 17,810.2 billion 
yen, CFP from 44,980.5 to 80,438.8 kt-CO ${ }_{2}$ eq, and employment from 1,277,700 to 2,278,200 people. In Scenario 0, consumption was 32,034.7 billion yen, the CFP was $140,763.2 \mathrm{kt}-\mathrm{CO}_{2} \mathrm{eq}$, and employment was 4,156,100 people.

Furthermore, Table 4 shows the reduction rate by comparing results of each scenario. In the comparison of Scenario 1 vs. 2019, i.e., the worst case, the consumption loss was 20,540 billion yen $(-65.1 \%)$, the CFP reduction was $89,488 \mathrm{kt}-\mathrm{CO}_{2} \mathrm{eq}(-64.2 \%)$, and the employment loss was $2,677,000$ people $(-64.2 \%)$. In scenario 3 vs. 2019 , i.e., the best case, the consumption loss was 12,704 billion yen $(-39.1 \%)$, the CFP reduction was $54,030 \mathrm{kt}-\mathrm{CO}_{2} \mathrm{eq}(-37.5 \%)$, and the employment loss was $1,678,000$ people $(-37.5 \%)$. The values for Scenario 2 were between these two extremes, and Scenario 0 resulted in more economic, environmental, and social growth.

Table 3. Estimated results for each scenario.

\begin{tabular}{|c|c|c|c|c|c|}
\hline & \multirow{2}{*}{2019} & \multicolumn{4}{|c|}{2020} \\
\hline & & SR 1 & SR 2 & SR 3 & SR 0 \\
\hline Economic (B-JPY) & $30,514.5$ & 9974.2 & $12,033.1$ & $17,810.2$ & $32,034.7$ \\
\hline Environment (kt- $\left.\mathrm{CO}_{2} \mathrm{eq}\right)$ & $134,468.4$ & $44,980.5$ & $54,309.6$ & $80,438.8$ & $140,763.2$ \\
\hline Social (thousand people) & 3955.2 & 1277.7 & 1540.5 & 2278.2 & 4156.1 \\
\hline
\end{tabular}

The breakdown of the results from 2011 to 2020e is shown in Table A2 (consumption), Table A3 (carbon footprint $(\mathrm{CFP}))$, and Table A4 (employment). "SR" refers to the scenario described in Table 2.

Table 4. Reduction rate by comparing results of each scenario.

\begin{tabular}{ccccccccc}
\hline & 2020 SR 1 vs. 2019 & \multicolumn{2}{c}{ 2020 SR 2 vs. 2019 } & 2020 SR 3 vs. 2019 & 2020 SR 0 vs. 2019 \\
\hline Economic (B-JPY) & $-20,540$ & $-65.1 \%$ & $-18,481$ & $-57.8 \%$ & $-12,704$ & $-39.1 \%$ & 1520 & $104.5 \%$ \\
Environment (kt-CO ${ }_{2}$ eq) & $-89,488$ & $-64.2 \%$ & $-80,159$ & $-56.7 \%$ & $-54,030$ & $-37.5 \%$ & 6295 & $104.2 \%$ \\
Social (thousand people) & -2677 & $-64.2 \%$ & -2415 & $-58.3 \%$ & -1678 & $-37.5 \%$ & 201 & $104.6 \%$ \\
\hline \multicolumn{3}{c}{ "SR" refers to the scenario in Table 2.}
\end{tabular}

Figure 1a shows the results of categories. From these results, it can be confirmed that contributions to consumption and GHG are made by transportation, souvenirs, and shopping. In addition to transportation, souvenirs, and shopping, contributions to employment are also made by accommodation, food, and beverage. Figure $1 \mathrm{~b}$ shows the results of the breakdowns. These results confirm that consumption is composed of accommodation, food and beverage, bullet train, confectionary, and international flights.

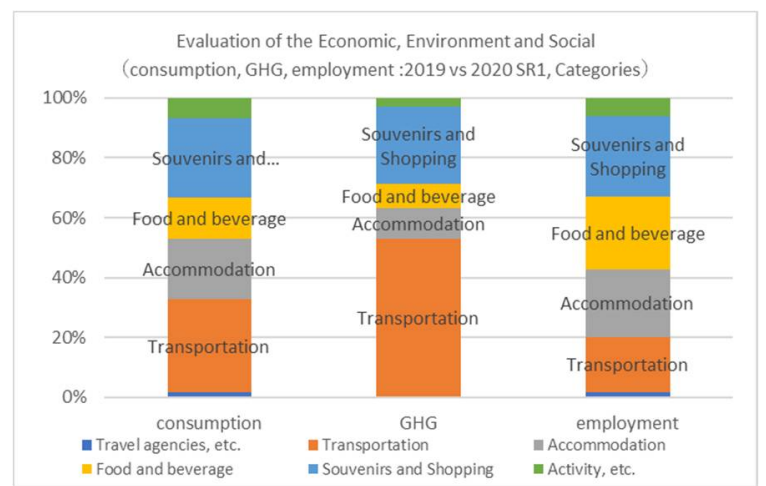

(a)

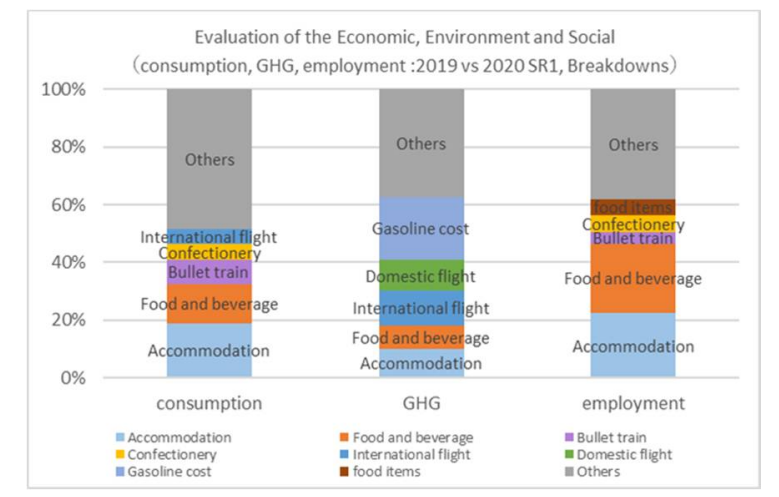

(b)

Figure 1. (a) Categories of significant contributions to the economy (consumption), environment (GHG), and society (employment). (b) Breakdown of significant contributions to the economy (consumption), environment (GHG), and society (employment).

Furthermore, GHG has a high impact due to the contribution of airplanes (international and domestic flight), gasoline cost, accommodation, and food and beverage. Employment includes 
accommodation and food and beverage, in addition to confectionery, food items, and bullet train contributions. This trend is almost the same for all years and scenarios (Figure 1a,b). Here, the breakdown of the top 5 contributions to the economy (consumption), environment (GHG), and society (employment) is shown clearly.

These results compare the CFP reduction and employer loss to the fall in the amount of consumption expenditure. From the perspective of the input-output table, CFP produces a large quantity of GHG emissions per production value. It is also shown that the number of employees is related to the value of production.

\subsection{Economic Analysis}

Figure 2 shows the results for tourist consumption from the economic evaluation. Figure 2a shows that the tourism economy grew from 2011 (detailed results are shown in Appendix A, Table A2), and Figure $2 \mathrm{~b}$ shows equivalent monthly data. In SR 1,2 , and 3 , the period from January until June shows the actual values of counted tourists. SR 1 was at the same level from June to December, SR 2 was at the level of June until September, followed by recovery from October, and SR 3 recovered from July. SR 0 is the same level as the past 10 years. Although the previous 10 years (2011-2019) experienced no major negatives, a large loss was confirmed for 2020. This is because tourism has experienced its worst situation of the past 10 years due to the influence of COVID-19.

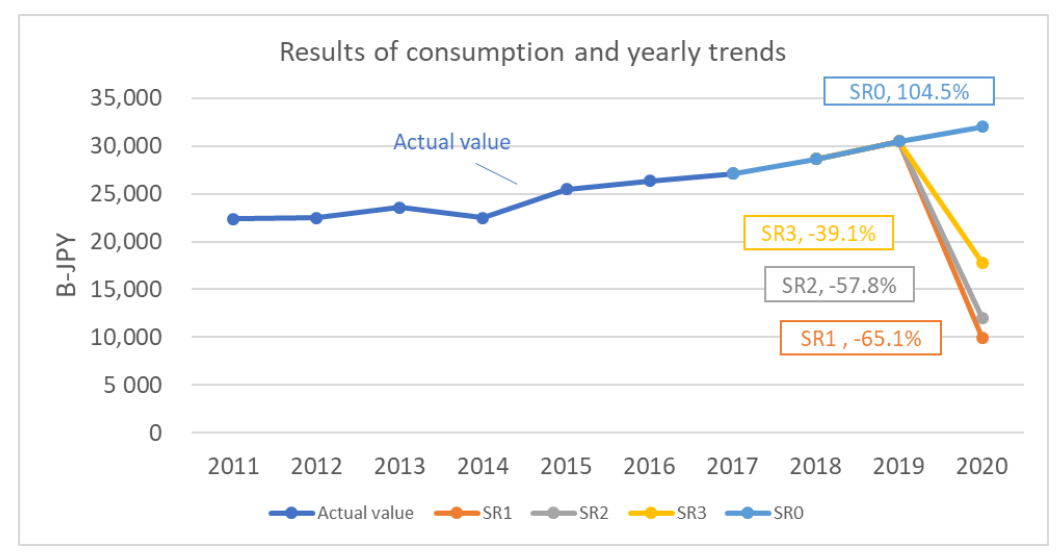

(a)

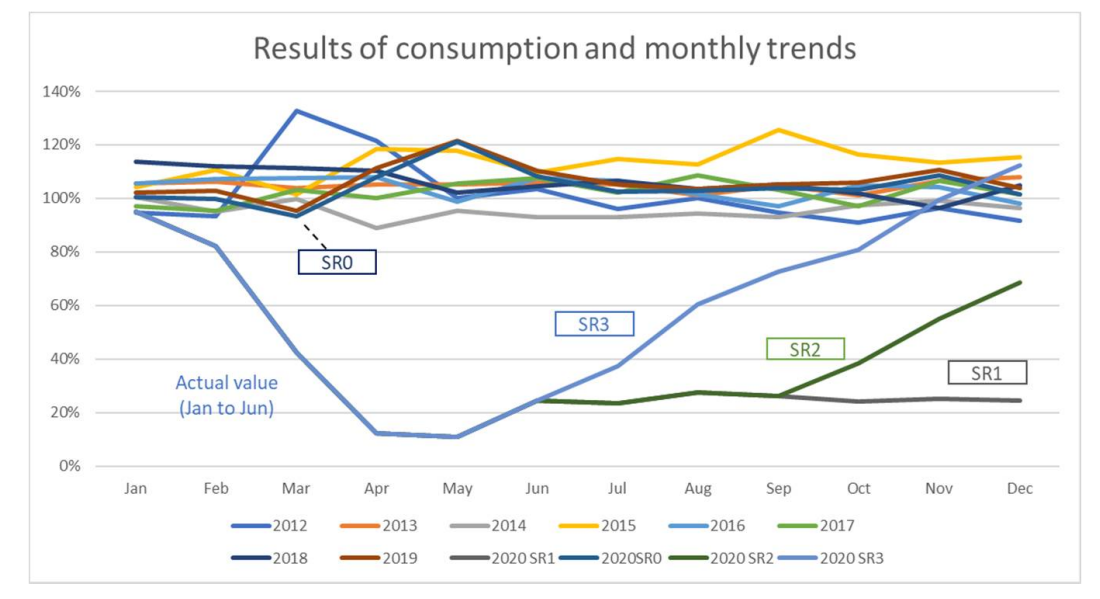

(b)

Figure 2. Results of a focus on tourist consumption: (a) yearly trends, (b) monthly trends. 


\subsection{Environmental Analysis}

Figure 3a shows the results for CFP from the environmental evaluation (detailed results are shown in Appendix A, Table A3) and indicates that tourism GHGs have increased annually since 2011. Figure $3 \mathrm{~b}$ shows the equivalent monthly data. In SR 1, 2, and 3, the period from January until June was based on the actual values of counted tourists. SR 1 was at the same level from June to December, SR 2 was at the level of June until September, before recovering from October, and SR 3 recovered from July. SR 0 was at the same level as that of the previous 10 years. Again, the figure shows that there was no major reduction during the past 10 years (2011-2019), and that a large reduction was confirmed for 2020. This is because the CFP associated with tourism has improved compared to the past 10 years due to the influence of COVID-19.

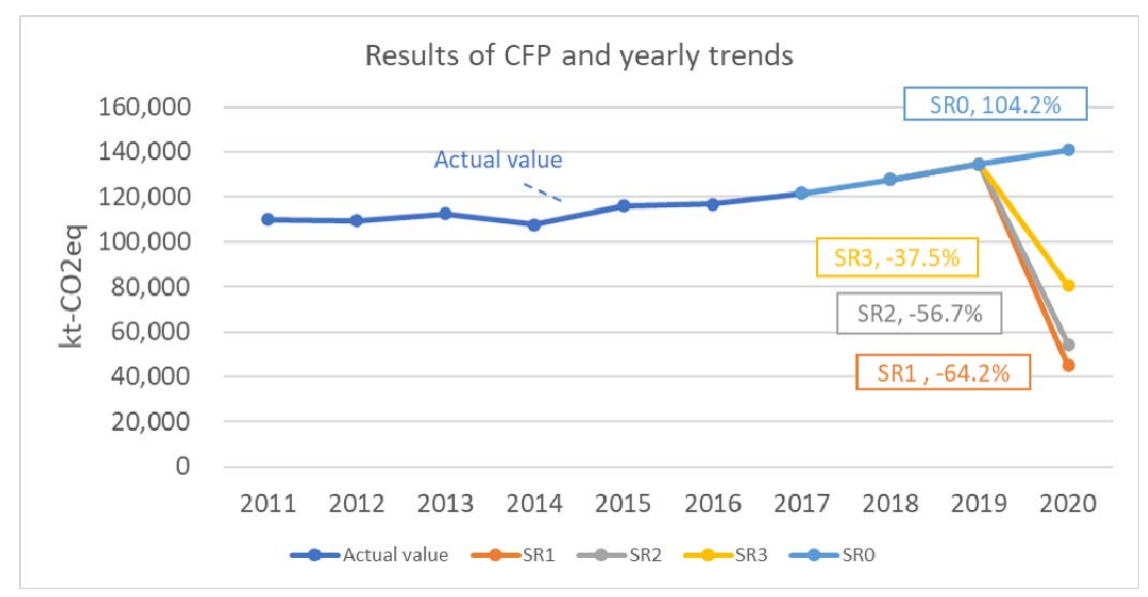

(a)

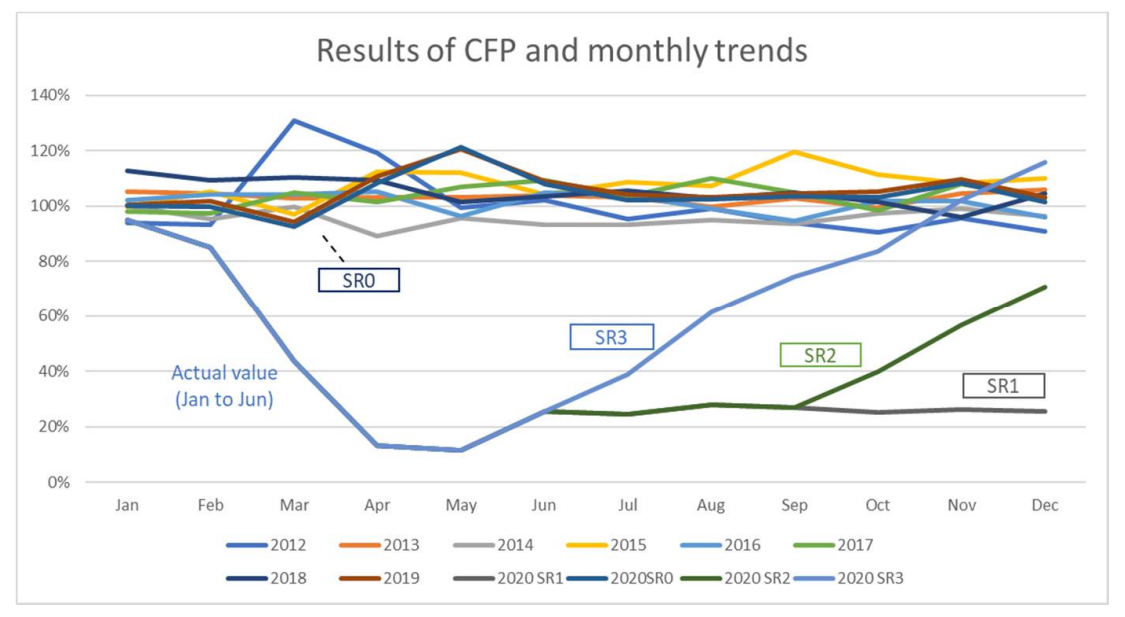

(b)

Figure 3. Results of the focus on CFP: (a) yearly trends, (b) monthly trends.

\subsection{Social Analysis}

Figure 4a shows the results for employment from the social evaluation (detailed results are shown in Appendix A, Table A4) and indicates the growth in tourism employment since 2011. Figure 4b provides the equivalent monthly data. In SR 1, 2, and 3, the period from January until June was based on the actual values of counted tourists. SR 1 was at the same level from June to December, SR 2 was at the level of June until September, followed by a recovery from October, and SR 3 recovered from July. SR 0 was at the same level as that of the past 10 years. As for the previous evaluations, no major reduction was seen during the past 10 years (2011-2019), and a large decline can be confirmed for 2020 . 
This is because tourism employment experienced its worst situation of the past 10 years due to the influence of COVID-19.

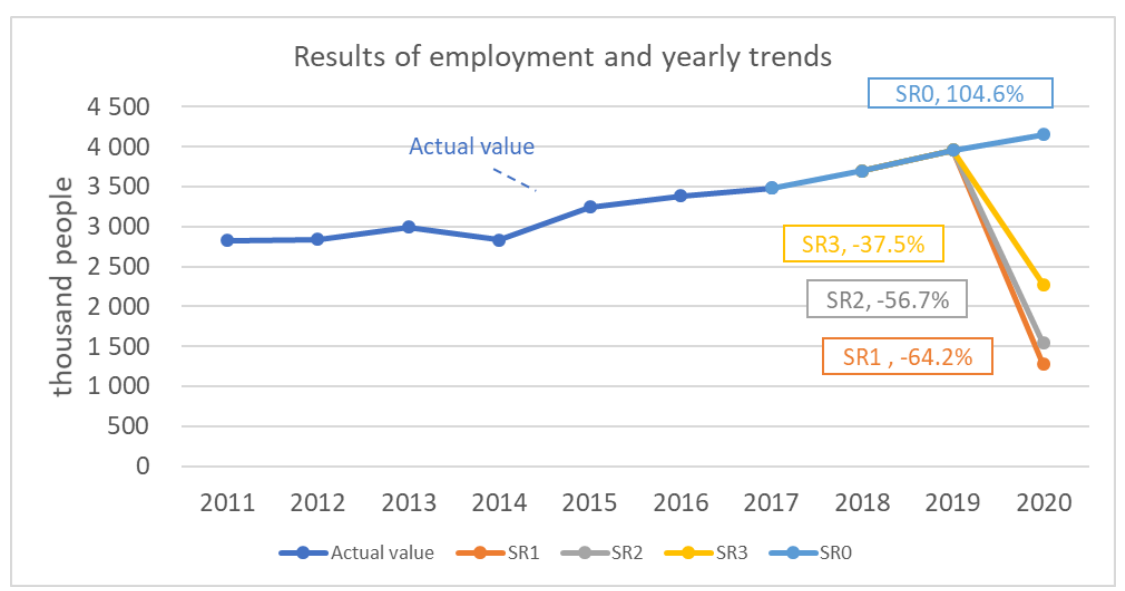

(a)

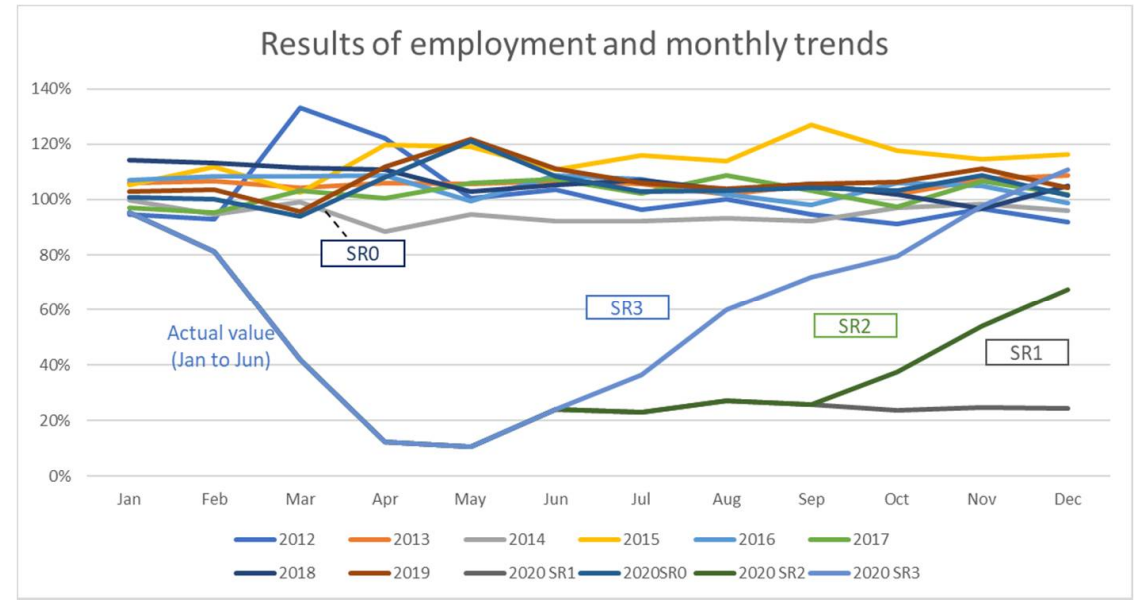

(b)

Figure 4. Results of focus on employment, (a) yearly trends, (b) monthly trends.

\section{Discussion}

\subsection{The current Economic Situation}

COVID-19 has had a severe impact on the global tourism industry [42]. The UNWTO report [17], updated with current scenarios, projects a decline of between $58 \%$ and $78 \%$ in international tourist arrivals for 2020, depending on the speed of the containment, the duration of travel restrictions, and the shutdown of borders. Based on international tourism receipts for 2000-2019 and scenarios for 2020, export revenues associated with global tourism could decline by between USD 910 billion (-62\%) and USD 1.2 trillion ( $-79 \%)$. Our study showed a consumption loss of between 12,704 billion yen $(-39.1 \%)$ and 20,540 billion yen (-65.1\%) in the case of Japan. The results of this study were included in the range of UNWTO's scenarios, albeit at the lower end of this range. This difference is related to the composition of Japan's tourism. According to The Japan Tourism White Paper (2017) [43], the value shares of tourism consumption in Japan are ranked as follows: domestic (overnight stay) $(60.2 \%)$, domestic (day trips) $(18.8 \%)$, inbound (16.5\%), and outbound (domestic transit) $(4.4 \%)$. Therefore, if the amount of inbound tourism decreases significantly, the economic impact will be small if supported by domestic travel. Following large losses, Japan's tourism industry is making a significant investment 
to encourage the recovery. A total budget of 1679.4 billion yen was allocated for the "Go To Travel Campaign" [44], which has three main pillars. In addition to efforts to support food and beverage, events, and entertainment, a public-private integrated tourism demand campaign will be implemented. This will include promotion of the use of discount coupons that can be widely used for accommodation and day trip products, souvenir shops, restaurants, tourist facilities, transportation facilities, etc., around tourist destinations. The campaign will also include large-scale advertising to support the resumption of suspended airlines and to attract international tourists to Japan. Food and beverages are usually included in the restaurant industry. However, there are economic spillovers from food and beverage related to the tourism industry. From 22 July to 15 September, this campaign involved at least 16.89 million tourist nights and about 73.5 billion yen of support [45]. This support will continue until the end of January, thus potentially reducing the economic impact of the pandemic.

\subsection{The Latest Situation of the Environmental Aspect}

The results of this study indicate that the recovery of tourism demand and employment are the top priorities. In addition, however, it was also confirmed that GHG emissions were greatly reduced. The target of the Paris Agreement for Japan is to reduce its CFP by 26\% by 2030 (compared to 2013) [4]. Lenzen et al. (2018) [22] calculated the carbon footprint of global tourism and found that tourism contributed about $8 \%$ of global GHG emissions. This highlights that the tourism industry has a significant responsibility to reduce its CFP. Furthermore, Kitamura et.al (2020) [29] estimated that tourism in Japan accounts for about $10.5 \%$ of the national CFP, accounting for approximately 136 million $\mathrm{t}-\mathrm{CO}_{2}$ per year, including outbound tourism. The contributions of each sector were found to be transport (56.3\%), souvenirs $(23.2 \%)$, accommodation $(9.8 \%)$, food and beverage $(7.5 \%)$, and activities (3.0\%). In the current study, the CFP was estimated to be 134,468.4 kt-CO $\mathrm{CO}_{2} \mathrm{eq}(2019)$, from $44,980.5$ to $80,438.8 \mathrm{kt}-\mathrm{CO}_{2} \mathrm{eq}$ (2020, SR 1 to 3), 140,763.2 kt-CO ${ }_{2} \mathrm{eq}(2020$, SR 0). CFP reductions were estimated to range from $89,488 \mathrm{kt}-\mathrm{CO}_{2}$ eq $(-64.2 \%)$ to $54,030 \mathrm{kt}-\mathrm{CO}_{2} \mathrm{eq}(-37.5 \%)$. The CFP of the tourism industry has been reduced beyond the goals of the Paris Agreement; thus, the tourism industry has made a large contribution to the overall reduction in the CFP. Despite this large reduction, however, the need for further reductions is well recognized due to the Japanese government's declaration to achieve net zero emissions by 2050. [5] In "Implications of COVID-19 for the Environment and Sustainability", published by the Institute for Global Environmental Strategies (IGES) [46], basic policy recommendations to promote a green recovery highlight the importance of Japan's emergency economic measures including environmental policies, such as meeting $100 \%$ of electricity demand from renewable energy sources (RE100). A recovery that prioritizes the economy is essential. However, the reductions in GHG emissions during this short pandemic period should not be reversed. As noted by Cooper et al. (2020) [31], the reduction in GHG emissions resulting from the death of the economy is not sustainable tourism. In business tourism (the MICE sector), international conferences have been held without the use of transportation for all participants [47]. Thus, in addition to transportation, souvenirs, accommodation, food and beverage, and activities at the destination also provide an opportunity for a major sustainability transformation towards decarbonization.

\subsection{The Latest Situation of Social Aspect}

The scenarios of the UNWTO report [17] show from 100 to 120 million direct tourism jobs are at risk globally. In addition, the International Labor Organization (ILO) reported the tourism sector accounted for $10.3 \%$ of global employment in 2019 [48]. The ILO notes that the pandemic could affect the work of 305 million people, many of whom are employed in the tourism sector. The Japanese Ministry of Internal Affairs and Communications (MIC) announced that the current level of employment is 59.46 million people and has been on a downward trend for five consecutive months. Furthermore, the number of unemployed is 2.06 million and has been on an increasing trend for seven consecutive months [49]. According to a report of the Japan Association of Travel Agents (JATA) [50], the tourism industry employs 2.31 million people, contributing $3.5 \%$ of total employment. This study estimated 
employment losses of between $2,677,000$ people $(-64.2 \%)$ and 1,678,000 people $(-37.5 \%)$. This result is comparable to the current number of unemployed. In addition, ANA Holdings Inc. released a full-year earnings forecast of -510 billion yen [51], and Japan airlines (JAL) also released its financial results [52]. For the largest airlines in Japan, such as ANA and JAL, management losses may affect the future employment of tourism industries. Thus, the future management situation of the tourism industry is unclear. However, growth in the number of travelers would also cause an increase in the number of overnight stays, indicating the potential for employment to recover.

\subsection{Limitations and Future Investigations}

Process-based LCA can reflect the effects of a reduction using physical quantities, such as resource usage, in evaluations. However, checking the supply chain is time-consuming and requires significant effort. Therefore, this study adopted input-output LCA based on consumption. However, individual products and services cannot be evaluated in detail. Environmental impact changes are dependent on monetary amounts, and it is difficult to reflect sustainability activities (resource efficiency, etc.) in the results. Process-based LCA is therefore required to allow examination of detailed changes. In addition, it is recommended to use monetary amounts and secondary data in the input-output LCA. Thus, we think it is necessary to evaluate the details with such a hybrid method. It should also be recognized that, because this evaluation was based on estimated scenarios based on the number of tourists, results are subject to a degree of uncertainty. Furthermore, world tourism information is constantly updated, and this should be carefully referred to in future estimations and evaluations.

\section{Conclusions}

In this study, the contributions of consumption, CFP, and employment of the Japanese tourism industry were shown for a 10-year period. Based on scenarios estimated using the number of tourists, we assessed the impact on consumption, CFP, and employment of the COVID-19 pandemic. In the worst case, consumption fell 20,540 billion yen (-65.1\%), the CFP was reduced by $89,488 \mathrm{kt}-\mathrm{CO}_{2} \mathrm{eq}(-64.2 \%)$, and employment fell by $2,677,000$ people $(-64.2 \%)$. Conversely, in the best case, the consumption loss was 12,704 billion yen $(-39.1 \%)$, the CFP reduction was $54,030 \mathrm{kt}-\mathrm{CO}_{2} \mathrm{eq}(-37.5 \%)$, and the employment loss was $1,678,000$ people $(-37.5 \%)$. These results reflect the deterioration in the economic and employment status of tourism to its worst situation in the past 10 years due to the influence of COVID-19. In contrast, the reduction in the tourism CFP represents a significant improvement. Overall, these results confirm the large influence of tourism and highlight the substantial opportunity for the industry due to its significant effects on the economy and employment. The CFP of tourism is largely focused on transportation. However, a transformation is necessary for the tourism industry to make a significant contribution to reducing global GHG emissions. Our hope is that the post-COVID-19 pandemic period is characterized by a sustainable recovery of the economy, societal health, and the environment. In this period, it will be necessary to maintain the reduced level of GHG emissions and to realize economic recovery. This recovery must also be sustainable for tourism stakeholders and society.

Author Contributions: Conceptualization: Y.K. and N.I.; methodology: Y.K., Y.I. and N.I.; writing-original draft preparation: Y.K. and S.K.; supervision: N.I. All authors have read and agreed to the published version of the manuscript.

Funding: This research received no external funding.

Acknowledgments: We would like to express our gratitude to Haruo Suzuki for his generous support of our study.

Conflicts of Interest: The authors declare no conflict of interest. 


\section{Appendix A}

Table A1. Sector row code table of the input-output table items by sector for carbon footprint (CFP) and number of employees. Created by the author based on Kitamura, Y. et al. (2020) [29] and Ichisugi, Y. et al. (2017) [41].

\begin{tabular}{|c|c|c|c|c|c|c|}
\hline \multirow{3}{*}{ Product and Service } & \multicolumn{4}{|c|}{ Coefficient } & \multirow{2}{*}{\multicolumn{2}{|c|}{ Input-Output Table Items }} \\
\hline & \multicolumn{3}{|c|}{ Social (Employment) } & \multirow{2}{*}{$\begin{array}{c}\text { Environment (CFP) } \\
\left(\mathrm{kg}-\mathrm{CO}_{2} \mathrm{eq} / \mathrm{JPY}\right)\end{array}$} & & \\
\hline & (Paid Officer/JPY) & $\begin{array}{c}\text { (Permanent } \\
\text { Employer/JPY) }\end{array}$ & $\begin{array}{c}\text { Temporary } \\
\text { Employer/JPY) }\end{array}$ & & Low Code & Code Name \\
\hline \multicolumn{7}{|c|}{ Travel agencies, tour operators and tourist guide services } \\
\hline $\begin{array}{l}\text { Travel agencies, tour operators, } \\
\text { and tourist guide services }\end{array}$ & $7.10 \times 10^{-9}$ & $1.25 \times 10^{-7}$ & $7.92 \times 10^{-9}$ & $6.88 \times 10^{-4}$ & 5789090 & $\begin{array}{c}\text { Travel and other transportation } \\
\text { incidental services }\end{array}$ \\
\hline \multicolumn{7}{|c|}{ Passenger transport } \\
\hline Airplane (domestic, local) & $3.75 \times 10^{-9}$ & $7.61 \times 10^{-8}$ & $3.53 \times 10^{-9}$ & $1.01 \times 10^{-2}$ & 5751010 & Air transport \\
\hline Airplane (international flight) & $3.75 \times 10^{-9}$ & $7.61 \times 10^{-8}$ & $3.53 \times 10^{-9}$ & $1.01 \times 10^{-2}$ & 5751010 & Air transport \\
\hline Bullet train & $2.36 \times 10^{-9}$ & $5.67 \times 10^{-8}$ & $2.51 \times 10^{-9}$ & $1.64 \times 10^{-3}$ & 5711010 & Railway transport \\
\hline Railways (excluding bullet train) & $2.36 \times 10^{-9}$ & $5.67 \times 10^{-8}$ & $2.51 \times 10^{-9}$ & $1.64 \times 10^{-3}$ & 5711010 & Railway transport \\
\hline Bus & $6.31 \times 10^{-9}$ & $1.63 \times 10^{-7}$ & $5.34 \times 10^{-9}$ & $4.16 \times 10^{-3}$ & 5721010 & Bus \\
\hline Taxi & $9.36 \times 10^{-9}$ & $2.08 \times 10^{-7}$ & $4.89 \times 10^{-9}$ & $4.93 \times 10^{-3}$ & 5721020 & Taxi \\
\hline Ships (inner service, local) & $6.52 \times 10^{-9}$ & $8.17 \times 10^{-8}$ & $4.20 \times 10^{-9}$ & $1.23 \times 10^{-2}$ & 5742010 & Marine and inland water \\
\hline Ships (outbound) & $3.71 \times 10^{-9}$ & $5.77 \times 10^{8}$ & $2.63 \times 10^{-9}$ & $2.57 \times 10^{-3}$ & 5741010 & Ocean \\
\hline Car rental fee & $4.37 \times 10^{-9}$ & $5.25 \times 10^{-8}$ & $2.05 \times 10^{-9}$ & $7.86 \times 10^{-4}$ & 6612010 & Car rental \\
\hline Gasoline cost & $2.69 \times 10^{-9}$ & $4.20 \times 10^{-8}$ & $1.76 \times 10^{-9}$ & $7.55 \times 10^{-3}$ & 2111010 & Petrol \\
\hline & - & - & - & $2.10 \times 10^{-2}$ & - & Petrol (direct) \\
\hline $\begin{array}{l}\text { Parking lot, toll road charge (except for } \\
\text { highway charge), highway charge }\end{array}$ & $6.92 \times 10^{-9}$ & $5.83 \times 10^{-8}$ & $2.76 \times 10^{-9}$ & $8.98 \times 10^{-4}$ & 5789010 & Road \\
\hline Highway charge & $6.92 \times 10^{-9}$ & $5.83 \times 10^{-8}$ & $2.76 \times 10^{-9}$ & $8.98 \times 10^{-4}$ & 5789010 & Road \\
\hline \multicolumn{7}{|c|}{ Accommodation services } \\
\hline Accommodation services & $8.64 \times 10^{-9}$ & $1.30 \times 10^{-7}$ & $1.64 \times 10^{-8}$ & $2.33 \times 10^{-3}$ & 6711010 & Accommodation \\
\hline Vacation home ownership (imputed) & $1.49 \times 10^{-9}$ & $1.35 \times 10^{-8}$ & $6.17 \times 10^{-10}$ & $2.37 \times 10^{-4}$ & 5531010 & $\begin{array}{l}\text { Vacation home ownership } \\
\text { (imputed) }\end{array}$ \\
\hline \multicolumn{7}{|c|}{ Food and beverage } \\
\hline Food and beverage serving services & $9.81 \times 10^{-9}$ & $1.96 \times 10^{-7}$ & $2.41 \times 10^{-8}$ & $2.59 \times 10^{-3}$ & 6721010 & Food and beverage \\
\hline \multicolumn{7}{|c|}{ Souvenirs and Shopping } \\
\hline Agricultural products & $5.46 \times 10^{-9}$ & $3.99 \times 10^{-8}$ & $1.99 \times 10^{-8}$ & $2.10 \times 10^{-3}$ & 116090 & \multirow{4}{*}{$\begin{array}{l}\text { Other non-food cropping crops } \\
\text { Agro-preserved food products } \\
\text { (except bottles and cans) } \\
\text { Inland fishery and aquaculture } \\
\text { Other seafood }\end{array}$} \\
\hline Agricultural processed products & $7.93 \times 10^{-9}$ & $1.07 \times 10^{-7}$ & $1.09 \times 10^{-8}$ & $3.12 \times 10^{-3}$ & 1116020 & \\
\hline Marine products & $1.86 \times 10^{-8}$ & $1.28 \times 10^{-7}$ & $3.49 \times 10^{-8}$ & $6.07 \times 10^{-3}$ & 172001 & \\
\hline Fisheries processed products & $8.85 \times 10^{-9}$ & $1.10 \times 10^{-7}$ & $9.34 \times 10^{-9}$ & $5.04 \times 10^{-3}$ & 1113090 & \\
\hline
\end{tabular}


Table A1. Cont.

\begin{tabular}{|c|c|c|c|c|c|c|}
\hline \multirow{3}{*}{ Product and Service } & \multicolumn{4}{|c|}{ Coefficient } & \multirow{2}{*}{\multicolumn{2}{|c|}{ Input-Output Table Items }} \\
\hline & \multicolumn{3}{|c|}{ Social (Employment) } & \multirow{2}{*}{$\begin{array}{c}\text { Environment (CFP) } \\
\left(\mathrm{kg}-\mathrm{CO}_{2} \mathrm{eq} / \mathrm{JPY}\right)\end{array}$} & & \\
\hline & (Paid Officer/JPY) & $\begin{array}{c}\text { (Permanent } \\
\text { Employer/JPY) }\end{array}$ & $\begin{array}{c}\text { Temporary } \\
\text { Employer/JPY) }\end{array}$ & & Low Code & Code Name \\
\hline Confectionery & $9.41 \times 10^{-9}$ & $1.22 \times 10^{-7}$ & $1.24 \times 10^{-8}$ & $3.66 \times 10^{-3}$ & 1115030 & Confectionery \\
\hline Other food items & $1.27 \times 10^{-8}$ & $1.34 \times 10^{-7}$ & $1.71 \times 10^{-8}$ & $5.54 \times 10^{-3}$ & 1119090 & Food items \\
\hline Fiber products & $1.04 \times 10^{-8}$ & $1.29 \times 10^{-7}$ & $5.58 \times 10^{-9}$ & $6.58 \times 10^{-3}$ & 1519090 & Textile products \\
\hline Shoes, bags & $8.51 \times 10^{-9}$ & $1.16 \times 10^{-7}$ & $7.23 \times 10^{-9}$ & $3.05 \times 10^{-3}$ & 2229010 & Footwear \\
\hline Ceramics and glass products & $1.23 \times 10^{-8}$ & $1.55 \times 10^{-7}$ & $9.54 \times 10^{-9}$ & $2.91 \times 10^{-3}$ & 2312020 & $\begin{array}{l}\text { Bags, bags and other } \\
\text { leather products }\end{array}$ \\
\hline Publication & $8.92 \times 10^{-9}$ & $9.81 \times 10^{-8}$ & $5.41 \times 10^{-9}$ & $3.43 \times 10^{-3}$ & 5951030 & Publication \\
\hline Wood products and paper products & $7.33 \times 10^{-9}$ & $9.46 \times 10^{-8}$ & $3.83 \times 10^{-9}$ & $5.62 \times 10^{-3}$ & 1649090 & $\begin{array}{l}\text { Other pulp, paper and } \\
\text { paper products }\end{array}$ \\
\hline Medical supplies and Cosmetics & $5.31 \times 10^{-9}$ & $8.08 \times 10^{-8}$ & $4.08 \times 10^{-9}$ & $3.69 \times 10^{-3}$ & 2081020 & Cosmetics \\
\hline Film & $5.48 \times 10^{-9}$ & $8.29 \times 10^{-8}$ & $2.94 \times 10^{-9}$ & $6.18 \times 10^{-3}$ & 2083010 & Photosensitive material \\
\hline Electrical equipment and related products & $5.42 \times 10^{-9}$ & $9.09 \times 10^{-8}$ & $3.83 \times 10^{-9}$ & $3.61 \times 10^{-3}$ & 3321020 & $\begin{array}{l}\text { Consumer electrical appliances } \\
\text { (except air conditioners) }\end{array}$ \\
\hline Camera, glasses, watch & $8.57 \times 10^{-9}$ & $1.19 \times 10^{-7}$ & $6.18 \times 10^{-9}$ & $3.26 \times 10^{-3}$ & 3919090 & $\begin{array}{l}\text { Other manufactured } \\
\text { industrial products }\end{array}$ \\
\hline Sports equipment $\cdot \mathrm{CD} \cdot$ stationery & $8.57 \times 10^{-9}$ & $1.19 \times 10^{-7}$ & $6.18 \times 10^{-9}$ & $3.26 \times 10^{-3}$ & 3919090 & $\begin{array}{l}\text { Other manufactured } \\
\text { industrial products }\end{array}$ \\
\hline Other manufactured products & $8.57 \times 10^{-9}$ & $1.19 \times 10^{-7}$ & $6.18 \times 10^{-9}$ & $3.26 \times 10^{-3}$ & 3919090 & $\begin{array}{l}\text { Other manufactured } \\
\text { industrial products }\end{array}$ \\
\hline \multicolumn{7}{|c|}{ Activity (Cultural services, Recreation and other entertainment services, and other services) } \\
\hline $\begin{array}{l}\text { A day spa warm-bathing } \\
\text { facility beauty salon }\end{array}$ & $8.31 \times 10^{-9}$ & $1.44 \times 10^{-7}$ & $1.63 \times 10^{-8}$ & $3.81 \times 10^{-3}$ & 6731040 & Bathing \\
\hline $\begin{array}{c}\text { Museums, museums, } \\
\text { zoos and gardens, aquariums }\end{array}$ & $3.12 \times 10^{-9}$ & $1.23 \times 10^{-7}$ & $2.91 \times 10^{-8}$ & $2.30 \times 10^{-3}$ & 6312010 & Social education (public) \\
\hline Watching sports and Art appreciation & $5.52 \times 10^{-9}$ & $7.73 \times 10^{-8}$ & $1.60 \times 10^{-8}$ & $1.01 \times 10^{-3}$ & 6741020 & $\begin{array}{c}\text { Office space } \\
\text { (except movie theaters) and } \\
\text { entertainment companies }\end{array}$ \\
\hline Amusement parks and expositions & $5.52 \times 10^{-9}$ & $7.73 \times 10^{-8}$ & $1.60 \times 10^{-8}$ & $1.01 \times 10^{-3}$ & 6741020 & $\begin{array}{l}\text { Office space } \\
\text { (except movie theaters) and } \\
\text { entertainment companies }\end{array}$ \\
\hline Sports Facilities & $5.97 \times 10^{-9}$ & $1.29 \times 10^{-7}$ & $1.80 \times 10^{-8}$ & $1.34 \times 10^{-3}$ & 6741040 & $\begin{array}{c}\text { Sports facility offer work, park, } \\
\text { amusement park }\end{array}$ \\
\hline Ski lift fee & $2.36 \times 10^{-9}$ & $5.67 \times 10^{-8}$ & $2.51 \times 10^{-9}$ & $1.64 \times 10^{-3}$ & 5711010 & Railway \\
\hline camp site & $5.97 \times 10^{-9}$ & $1.29 \times 10^{-7}$ & $1.80 \times 10^{-8}$ & $1.34 \times 10^{-3}$ & 6741040 & $\begin{array}{l}\text { Sports facility offer work, } \\
\text { park, amusement park }\end{array}$ \\
\hline
\end{tabular}


Table A1. Cont.

\begin{tabular}{|c|c|c|c|c|c|c|}
\hline \multirow{3}{*}{ Product and Service } & \multicolumn{4}{|c|}{ Coefficient } & \multirow{2}{*}{\multicolumn{2}{|c|}{ Input-Output Table Items }} \\
\hline & \multicolumn{3}{|c|}{ Social (Employment) } & \multirow{2}{*}{$\begin{array}{c}\text { Environment (CFP) } \\
\left(\mathrm{kg}-\mathrm{CO}_{2} \mathrm{eq} / \mathrm{JPY}\right)\end{array}$} & & \\
\hline & (Paid Officer/JPY) & $\begin{array}{c}\text { (Permanent } \\
\text { Employer/JPY) }\end{array}$ & $\begin{array}{c}\text { Temporary } \\
\text { Employer/JPY) }\end{array}$ & & Low Code & Code Name \\
\hline $\begin{array}{l}\text { Exhibition and convention } \\
\text { participation fee }\end{array}$ & $8.48 \times 10^{-9}$ & $8.87 \times 10^{-8}$ & $7.87 \times 10^{-9}$ & $6.27 \times 10^{-4}$ & 6699090 & Other business services \\
\hline Tourist farm & $4.05 \times 10^{-9}$ & $1.03 \times 10^{-7}$ & $2.04 \times 10^{-8}$ & $4.56 \times 10^{-3}$ & 131020 & $\begin{array}{l}\text { Agricultural services (except for } \\
\text { veterinary services) }\end{array}$ \\
\hline $\begin{array}{l}\text { Fishing boat } \\
\text { Guide fee }\end{array}$ & $\begin{array}{l}6.78 \times 10^{-9} \\
6.60 \times 10^{-9}\end{array}$ & $\begin{array}{l}1.27 \times 10^{-7} \\
8.15 \times 10^{-8}\end{array}$ & $\begin{array}{l}1.44 \times 10^{-8} \\
1.37 \times 10^{-8}\end{array}$ & $\begin{array}{l}1.45 \times 10^{-3} \\
8.22 \times 10^{-4}\end{array}$ & $\begin{array}{l}6741090 \\
6799090\end{array}$ & $\begin{array}{l}\text { Other entertainment } \\
\text { Other personal services }\end{array}$ \\
\hline Rental charge & $4.94 \times 10^{-9}$ & $5.63 \times 10^{-8}$ & $2.72 \times 10^{-9}$ & $7.80 \times 10^{-4}$ & 6611010 & $\begin{array}{l}\text { Goods rental business } \\
\text { (excluding rental cars) }\end{array}$ \\
\hline Massage & $6.28 \times 10^{-9}$ & $1.37 \times 10^{-7}$ & $9.55 \times 10^{-9}$ & $1.06 \times 10^{-3}$ & 6411050 & Medical (other medical services) \\
\hline Photo shoot fee & $1.39 \times 10^{-8}$ & $1.11 \times 10^{-7}$ & $1.61 \times 10^{-8}$ & $1.10 \times 10^{-3}$ & 6799010 & Photography \\
\hline Mail and communication charges & $1.58 \times 10^{-9}$ & $2.01 \times 10^{-7}$ & $4.28 \times 10^{-9}$ & $1.51 \times 10^{-3}$ & 5791010 & Postal and letter mail \\
\hline Home delivery & $8.47 \times 10^{-9}$ & $1.42 \times 10^{-7}$ & $9.28 \times 10^{-9}$ & $1.38 \times 10^{-2}$ & 5722010 & Delivery \\
\hline $\begin{array}{c}\text { Travel insurance } \cdot \text { Credit card } \\
\text { admission fee }\end{array}$ & $3.87 \times 10^{-9}$ & $9.13 \times 10^{-8}$ & $2.27 \times 10^{-9}$ & $6.78 \times 10^{-4}$ & 5312010 & Life insurance \\
\hline Passport application fee & $2.34 \times 10^{-9}$ & $7.28 \times 10^{-8}$ & $3.04 \times 10^{-9}$ & $8.16 \times 10^{-4}$ & 6112010 & Government (local) \\
\hline Visa application fee & $2.34 \times 10^{-9}$ & $7.28 \times 10^{-8}$ & $3.04 \times 10^{-9}$ & $8.16 \times 10^{-4}$ & 6112010 & Government (local) \\
\hline Hairdresser/Barber & $8.45 \times 10^{-9}$ & $1.18 \times 10^{-7}$ & $1.16 \times 10^{-8}$ & $9.50 \times 10^{-4}$ & 6731030 & Beauty industry \\
\hline Develop and print photos & $6.60 \times 10^{-9}$ & $8.15 \times 10^{-8}$ & $1.37 \times 10^{-8}$ & $8.22 \times 10^{-4}$ & 6799090 & Other personal services \\
\hline laundry service & $6.77 \times 10^{-9}$ & $1.42 \times 10^{-7}$ & $1.28 \times 10^{-8}$ & $1.74 \times 10^{-3}$ & 6731010 & Laundry service \\
\hline Other & $6.60 \times 10^{-9}$ & $8.15 \times 10^{-8}$ & $1.37 \times 10^{-8}$ & $8.22 \times 10^{-4}$ & 6799090 & Other personal services \\
\hline
\end{tabular}

Table A2. Results of tourist consumption breakdown (2011-2020).

\begin{tabular}{|c|c|c|c|c|c|c|c|c|c|c|c|c|c|}
\hline \multirow{2}{*}{ Products } & \multirow{2}{*}{2011} & \multirow{2}{*}{2012} & \multirow{2}{*}{2013} & \multirow{2}{*}{2014} & \multirow{2}{*}{2015} & \multirow{2}{*}{2016} & \multirow{2}{*}{2017} & \multirow{2}{*}{2018} & \multirow{2}{*}{2019} & \multicolumn{4}{|c|}{2020} \\
\hline & & & & & & & & & & SR1 & SR2 & SR3 & SRO \\
\hline Travel agencies, operators, and guides & & & & & & & & & & & & & \\
\hline Travel agencies, tour operators, and tourist guide services & 415.9 & 436.7 & 457.0 & 424.2 & 454.1 & 438.1 & 439.2 & 450.4 & 463.3 & 135.3 & 160.3 & 230.6 & 470.9 \\
\hline Transport & & & & & & & & & & & & & \\
\hline Airplane (domestic, local) & 1314.0 & 1304.5 & 1319.0 & 1348.1 & 1464.0 & 1395.1 & 1438.9 & 1469.6 & 1502.2 & 576.0 & 708.9 & 1085.9 & 1606.3 \\
\hline Airplane (international flight) & 708.1 & 747.1 & 818.0 & 921.4 & 976.2 & 962.0 & 1052.0 & 1141.6 & 1255.1 & 180.9 & 182.8 & 185.0 & 1210.7 \\
\hline Bullet train & 1743.1 & 1873.6 & 1952.0 & 1981.2 & 2364.6 & 2489.8 & 2352.6 & 2472.2 & 2614.0 & 910.1 & 1104.0 & 1646.8 & 2755.7 \\
\hline Railways (excluding bullet train) & 753.9 & 711.8 & 771.0 & 662.2 & 751.6 & 766.8 & 729.2 & 743.8 & 758.7 & 299.5 & 366.4 & 553.3 & 799.9 \\
\hline Bus & 525.0 & 460.8 & 471.0 & 373.9 & 395.3 & 434.3 & 439.6 & 448.6 & 457.8 & 181.5 & 221.7 & 333.7 & 481.2 \\
\hline Taxi & 157.9 & 150.6 & 161.0 & 181.4 & 194.8 & 233.8 & 211.7 & 230.9 & 254.7 & 73.4 & 87.3 & 126.5 & 266.6 \\
\hline Ships (inner service, local) & 104.5 & 107.2 & 101.0 & 100.5 & 110.8 & 110.5 & 114.0 & 117.6 & 121.6 & 45.2 & 55.5 & 84.7 & 130.1 \\
\hline
\end{tabular}


Table A2. Cont.

\begin{tabular}{|c|c|c|c|c|c|c|c|c|c|c|c|c|c|}
\hline \multirow[b]{2}{*}{ Products } & \multirow[b]{2}{*}{2011} & \multirow[b]{2}{*}{2012} & \multirow[b]{2}{*}{2013} & \multirow[b]{2}{*}{2014} & \multirow[b]{2}{*}{2015} & \multirow[b]{2}{*}{2016} & \multirow[b]{2}{*}{2017} & \multirow[b]{2}{*}{2018} & \multirow[b]{2}{*}{2019} & \multicolumn{4}{|c|}{2020} \\
\hline & & & & & & & & & & SR1 & SR2 & SR3 & SR0 \\
\hline Ships (outbound) & 4.1 & 3.9 & 3.0 & 4.9 & 5.5 & 4.3 & 4.7 & 4.9 & 5.2 & 0.8 & 0.8 & 0.8 & 4.9 \\
\hline Car rental fee & 260.3 & 274.1 & 322.0 & 259.9 & 302.8 & 361.8 & 344.9 & 362.2 & 382.7 & 132.6 & 161.5 & 243.1 & 406.5 \\
\hline Gasoline cost & 1211.2 & 1189.2 & 1189.0 & 1096.7 & 1047.5 & 1013.2 & 1102.5 & 1125.3 & 1148.5 & 460.6 & 564.1 & 852.8 & 1212.7 \\
\hline Parking lot, toll road charge (except for highway charge) & 378.0 & 260.4 & 260.0 & 314.7 & 279.8 & 279.8 & 291.4 & 297.2 & 303.1 & 118.8 & 145.2 & 218.8 & 318.8 \\
\hline Highway charge & 660.7 & 754.8 & 798.0 & 738.5 & 844.6 & 891.5 & 967.5 & 987.1 & 1007.2 & 402.4 & 493.2 & 746.7 & 1065.1 \\
\hline \multicolumn{14}{|l|}{ Accommodation } \\
\hline Accommodation services & 3478.9 & 3681.1 & 3844.0 & 3619.8 & 4305.7 & 4544.7 & 4791.4 & 5147.0 & 5582.5 & 1717.2 & 2074.7 & 3091.2 & 5927.8 \\
\hline Vacation home ownership (imputed) & 407.0 & 405.7 & 404.0 & 437.0 & 441.7 & 446.4 & 451.1 & 459.0 & 467.0 & 182.6 & 226.0 & 349.9 & 504.2 \\
\hline \multicolumn{14}{|l|}{ Food and beverage } \\
\hline Food and beverage serving services & 2422.3 & 2488.5 & 2724.0 & 2653.7 & 3142.8 & 3395.0 & 3514.2 & 3774.4 & 4091.7 & 1285.4 & 1545.8 & 2275.6 & 4304.8 \\
\hline \multicolumn{14}{|l|}{ Souvenirs } \\
\hline Agricultural products & 157.4 & 147.2 & 173.0 & 144.9 & 157.8 & 166.3 & 179.3 & 183.1 & 187.0 & 75.7 & 92.5 & 139.4 & 196.8 \\
\hline Agricultural processed products & 104.7 & 96.2 & 96.0 & 99.8 & 94.1 & 99.6 & 103.0 & 105.1 & 107.2 & 43.1 & 52.8 & 80.0 & 113.4 \\
\hline Marine products & 191.4 & 191.3 & 181.0 & 143.8 & 159.6 & 169.5 & 134.9 & 137.6 & 140.4 & 56.2 & 69.0 & 104.8 & 149.0 \\
\hline Fisheries processed products & 171.8 & 163.8 & 172.0 & 145.0 & 149.8 & 147.3 & 152.7 & 155.8 & 158.9 & 63.6 & 78.1 & 118.6 & 168.6 \\
\hline Confectionery & 1418.5 & 1418.2 & 1459.0 & 1367.4 & 1456.0 & 1489.9 & 1611.9 & 1677.9 & 1754.4 & 632.3 & 769.3 & 1153.2 & 1850.7 \\
\hline Other food items & 1086.1 & 1093.1 & 1136.0 & 1011.7 & 1193.8 & 1211.1 & 1207.6 & 1272.4 & 1349.4 & 463.2 & 560.5 & 832.1 & 1418.3 \\
\hline Fiber products & 1114.1 & 1059.6 & 1065.0 & 921.1 & 971.2 & 1076.1 & 981.9 & 1008.9 & 1038.7 & 383.6 & 467.7 & 703.9 & 1093.9 \\
\hline Shoes, bags & 523.7 & 490.1 & 650.0 & 592.7 & 784.9 & 712.5 & 708.8 & 786.3 & 882.8 & 225.3 & 263.4 & 369.4 & 914.2 \\
\hline Ceramics and glass products & 58.8 & 64.8 & 46.0 & 52.5 & 50.4 & 46.5 & 42.3 & 43.1 & 44.0 & 17.5 & 21.5 & 32.9 & 46.9 \\
\hline Publication & 104.0 & 107.0 & 111.0 & 94.0 & 106.3 & 107.0 & 101.1 & 107.6 & 115.5 & 35.9 & 43.0 & 62.6 & 120.2 \\
\hline Wood products and paper products & 44.9 & 42.0 & 33.0 & 28.5 & 34.9 & 32.0 & 41.5 & 42.4 & 43.3 & 17.5 & 21.4 & 32.3 & 45.6 \\
\hline Medical supplies and cosmetics & 190.1 & 204.9 & 222.0 & 292.1 & 530.6 & 607.2 & 676.3 & 826.8 & 1017.4 & 158.8 & 170.1 & 200.1 & 1044.9 \\
\hline Film & 12.2 & 14.6 & 11.0 & 5.9 & 8.3 & 8.5 & 7.1 & 7.2 & 7.3 & 2.7 & 3.3 & 5.0 & 7.7 \\
\hline Electrical equipment and related products & 247.7 & 204.2 & 185.0 & 234.8 & 246.4 & 204.8 & 223.5 & 254.4 & 293.2 & 64.5 & 73.8 & 99.5 & 302.1 \\
\hline Camera, glasses, watch & 196.7 & 178.0 & 205.0 & 196.6 & 244.7 & 198.4 & 229.3 & 253.5 & 283.6 & 71.9 & 84.2 & 118.3 & 293.8 \\
\hline Sports equipment $\cdot \mathrm{CD} \cdot$ stationery & 101.3 & 100.6 & 100.0 & 92.0 & 157.2 & 204.7 & 237.5 & 242.5 & 247.7 & 99.1 & 121.1 & 181.9 & 259.9 \\
\hline Other manufactured products & 146.1 & 141.2 & 142.0 & 157.5 & 176.2 & 202.5 & 199.2 & 221.3 & 248.6 & 67.9 & 80.0 & 113.7 & 259.0 \\
\hline \multicolumn{14}{|l|}{ Activities } \\
\hline A day spa warm-bathing facility beauty salon & 107.4 & 105.8 & 97.0 & 95.3 & 114.1 & 103.5 & 121.4 & 123.9 & 126.4 & 50.6 & 62.1 & 94.3 & 134.1 \\
\hline Museums, museums, zoos and gardens, aquariums & 137.5 & 149.2 & 144.0 & 140.1 & 160.4 & 169.3 & 178.2 & 188.4 & 200.6 & 68.6 & 83.0 & 123.4 & 211.3 \\
\hline Watching sports and art appreciation & 104.6 & 75.5 & 106.0 & 116.9 & 131.3 & 160.6 & 184.3 & 190.6 & 197.7 & 76.3 & 92.8 & 138.2 & 206.8 \\
\hline Amusement parks and expositions & 311.5 & 322.3 & 341.0 & 349.5 & 396.5 & 407.3 & 430.6 & 451.4 & 475.8 & 170.5 & 206.7 & 307.7 & 500.1 \\
\hline Sports Facilities & 121.1 & 124.9 & 163.0 & 129.5 & 136.1 & 137.3 & 132.3 & 135.3 & 138.4 & 56.6 & 68.9 & 103.0 & 144.5 \\
\hline Ski lift fee & 38.2 & 51.8 & 43.0 & 43.2 & 41.9 & 30.6 & 39.9 & 40.7 & 41.5 & 16.6 & 20.4 & 31.0 & 44.1 \\
\hline Camp site & 0.8 & 0.9 & 1.0 & 5.4 & 0.8 & 1.5 & 0.8 & 0.8 & 0.8 & 0.4 & 0.4 & 0.6 & 0.9 \\
\hline Exhibition and convention participation fee & 27.2 & 23.2 & 22.0 & 25.9 & 20.2 & 30.9 & 31.2 & 31.8 & 32.5 & 13.2 & 16.1 & 24.2 & 34.2 \\
\hline Tourist farm & 12.9 & 14.9 & 12.0 & 13.5 & 15.2 & 13.6 & 15.8 & 16.2 & 16.5 & 6.7 & 8.2 & 12.3 & 17.3 \\
\hline Fishing boat & 41.6 & 30.8 & 27.0 & 17.6 & 25.4 & 27.1 & 33.2 & 33.9 & 34.6 & 13.9 & 17.1 & 25.8 & 36.5 \\
\hline Guide fee & 19.9 & 28.9 & 28.0 & 23.3 & 39.7 & 34.3 & 32.4 & 33.1 & 33.8 & 13.6 & 16.6 & 25.2 & 35.7 \\
\hline Rental charge & 43.8 & 53.7 & 42.0 & 49.4 & 70.5 & 66.2 & 97.5 & 101.6 & 106.4 & 34.8 & 42.0 & 62.3 & 111.3 \\
\hline Massage & 50.9 & 45.4 & 47.0 & 41.4 & 30.1 & 30.2 & 34.9 & 35.5 & 36.1 & 14.2 & 17.6 & 27.0 & 38.8 \\
\hline Photo shoot fee & 25.2 & 18.9 & 24.0 & 25.3 & 18.2 & 17.8 & 14.7 & 15.0 & 15.3 & 6.1 & 7.5 & 11.4 & 16.2 \\
\hline Mail and communication charges & 25.2 & 17.3 & 14.0 & 20.0 & 8.6 & 15.8 & 14.2 & 14.5 & 14.8 & 5.6 & 6.8 & 10.3 & 15.6 \\
\hline
\end{tabular}


Table A2. Cont.

\begin{tabular}{|c|c|c|c|c|c|c|c|c|c|c|c|c|c|}
\hline \multirow{2}{*}{ Products } & \multirow[b]{2}{*}{2011} & \multirow{2}{*}{2012} & \multirow[b]{2}{*}{2013} & \multirow[b]{2}{*}{2014} & \multirow{2}{*}{2015} & \multirow[b]{2}{*}{2016} & \multirow{2}{*}{2017} & \multirow[b]{2}{*}{2018} & \multirow[b]{2}{*}{2019} & \multicolumn{4}{|c|}{2020} \\
\hline & & & & & & & & & & SR1 & SR2 & SR3 & SR0 \\
\hline Home delivery & 111.7 & 106.3 & 111.0 & 108.2 & 108.4 & 93.6 & 96.2 & 97.9 & 99.6 & 37.8 & 46.4 & 70.8 & 105.9 \\
\hline Travel insurance . Credit card admission fee & 54.6 & 56.3 & 52.0 & 37.0 & 39.8 & 63.9 & 60.9 & 61.5 & 62.1 & 17.0 & 19.9 & 27.9 & 61.9 \\
\hline Passport application fee & 43.7 & 47.9 & 44.0 & 43.5 & 38.1 & 42.6 & 41.4 & 41.4 & 41.5 & 6.5 & 6.6 & 6.7 & 38.3 \\
\hline Visa application fee & 0.0 & 0.0 & 0.0 & 0.0 & 0.0 & 0.0 & 0.0 & 0.0 & 0.0 & 0.0 & 0.0 & 0.0 & 0.0 \\
\hline Hairdresser/Barber & 261.2 & 232.9 & 254.0 & 208.7 & 214.0 & 238.9 & 229.1 & 233.5 & 238.0 & 92.5 & 113.2 & 171.3 & 251.3 \\
\hline Develop and print photos & 106.6 & 90.6 & 95.0 & 70.6 & 62.5 & 55.1 & 48.9 & 49.8 & 50.7 & 19.1 & 23.3 & 35.1 & 53.1 \\
\hline Laundry service & 56.3 & 58.4 & 53.0 & 45.7 & 59.5 & 50.9 & 53.5 & 54.5 & 55.5 & 21.5 & 26.4 & 40.0 & 58.7 \\
\hline Other & 267.5 & 269.8 & 259.0 & 192.4 & 145.7 & 130.1 & 143.3 & 151.5 & 161.4 & 51.0 & 60.9 & 88.3 & 166.9 \\
\hline Total & $22,383.8$ & $22,492.7$ & $23,560.0$ & $22,500.9$ & $25,481.3$ & $26,371.8$ & $27,117.4$ & $28,660.1$ & $30,514.5$ & 9974.2 & $12,033.1$ & $17,810.2$ & 32,034 \\
\hline
\end{tabular}

Table A3. Results of CFP breakdown (2011-2020).

\begin{tabular}{|c|c|c|c|c|c|c|c|c|c|c|c|c|c|}
\hline \multirow{2}{*}{ Products } & \multirow[b]{2}{*}{2011} & \multirow[b]{2}{*}{2012} & \multirow{2}{*}{2013} & \multirow[b]{2}{*}{2014} & \multirow[b]{2}{*}{2015} & \multirow[b]{2}{*}{2016} & \multirow[b]{2}{*}{2017} & \multirow[b]{2}{*}{2018} & \multirow[b]{2}{*}{2019} & \multicolumn{4}{|c|}{2020} \\
\hline & & & & & & & & & & SR1 & SR2 & SR3 & SRO \\
\hline \multicolumn{14}{|l|}{ Travel agencies, operators, and guides } \\
\hline Travel agencies, tour operators, and tourist guide services & 286.1 & 300.3 & 314.3 & 291.7 & 312.3 & 301.3 & 302.1 & 309.8 & 318.6 & 93.1 & 110.3 & 158.6 & 323.9 \\
\hline \multicolumn{14}{|l|}{ Transport } \\
\hline Airplane (domestic, local) & $13,244.4$ & $13,149.2$ & $13,295.0$ & $13,588.3$ & $14,756.7$ & $14,062.1$ & $14,503.2$ & $14,812.7$ & $15,141.4$ & 5806.3 & 7145.9 & $10,945.5$ & $16,190.6$ \\
\hline Airplane (international flight) & 7136.9 & 7530.3 & 8245.1 & 9287.6 & 9839.7 & 9696.5 & $10,604.1$ & $11,507.2$ & $12,650.6$ & 1822.9 & 1842.3 & 1864.9 & $12,203.5$ \\
\hline Bullet train & 2866.9 & 3081.6 & 3210.5 & 3258.6 & 3889.0 & 4094.9 & 3869.3 & 4066.1 & 4299.3 & 1496.8 & 1815.8 & 2708.5 & 4532.3 \\
\hline Railways (excluding bullet train) & 1239.9 & 1170.7 & 1268.1 & 1089.1 & 1236.2 & 1261.2 & 1199.3 & 1223.3 & 1247.8 & 492.5 & 602.6 & 910.1 & 1315.6 \\
\hline Bus & 2185.7 & 1918.6 & 1960.9 & 1556.6 & 1645.7 & 1808.3 & 1830.3 & 1867.7 & 1906.0 & 755.4 & 923.0 & 1389.3 & 2003.3 \\
\hline Taxi & 778.8 & 742.9 & 794.1 & 894.6 & 960.8 & 1153.2 & 1043.9 & 1138.9 & 1256.1 & 361.8 & 430.8 & 623.9 & 1315.0 \\
\hline Ships (inner service, local) & 1286.2 & 1319.0 & 1242.8 & 1237.2 & 1363.7 & 1360.0 & 1402.2 & 1446.5 & 1496.7 & 556.2 & 683.0 & 1042.6 & 1600.7 \\
\hline Ships (outbound) & 10.6 & 10.1 & 7.7 & 12.6 & 14.1 & 11.2 & 12.0 & 12.6 & 13.3 & 2.0 & 2.0 & 2.0 & 12.6 \\
\hline Car rental fee & 204.5 & 215.4 & 253.0 & 204.2 & 237.9 & 284.2 & 271.0 & 284.6 & 300.7 & 104.2 & 126.9 & 191.0 & 319.4 \\
\hline Gasoline cost & $34,611.7$ & $33,981.5$ & $33,976.4$ & $31,339.1$ & $29,933.6$ & $28,953.7$ & $31,505.5$ & $32,155.9$ & $32,820.4$ & $13,162.8$ & $16,120.9$ & $24,368.1$ & $34,654.8$ \\
\hline Parking lot, toll road charge (except for highway charge) & 339.3 & 233.8 & 233.4 & 282.5 & 251.2 & 251.2 & 261.6 & 266.8 & 272.1 & 106.6 & 130.3 & 196.4 & 286.2 \\
\hline Highway charge & 593.2 & 677.7 & 716.5 & 663.1 & 758.3 & 800.5 & 868.6 & 886.3 & 904.3 & 361.3 & 442.8 & 670.4 & 956.3 \\
\hline \multicolumn{14}{|l|}{ Accommodation } \\
\hline Accommodation se & 8111.5 & 8583.1 & 8962.8 & 8440.1 & $10,039.4$ & $10,596.6$ & $11,171.9$ & $12,001.0$ & $13,016.5$ & 4003.9 & 4837.4 & 7207.5 & $13,821.6$ \\
\hline Vacation home ownership (imputed) & 96.6 & 96.3 & 95.9 & 103.7 & 104.8 & 105.9 & 107.1 & 108.9 & 110.8 & 43.3 & 53.6 & 83.0 & 119.6 \\
\hline
\end{tabular}


Table A3. Cont.

\begin{tabular}{|c|c|c|c|c|c|c|c|c|c|c|c|c|c|}
\hline \multirow{2}{*}{ Products } & \multirow{2}{*}{2011} & \multirow{2}{*}{2012} & \multirow{2}{*}{2013} & \multirow{2}{*}{2014} & \multirow{2}{*}{2015} & \multirow{2}{*}{2016} & \multirow{2}{*}{2017} & \multirow{2}{*}{2018} & \multirow{2}{*}{2019} & \multicolumn{4}{|c|}{2020} \\
\hline & & & & & & & & & & SR1 & SR2 & SR3 & SR0 \\
\hline \multicolumn{14}{|l|}{ Food and beverage } \\
\hline Food and beverage serving services & 6262.2 & 6433.3 & 7042.1 & 6860.5 & 8124.8 & 8776.7 & 9084.9 & 9757.6 & $10,577.9$ & 3323.1 & 3996.1 & 5882.9 & $11,128.8$ \\
\hline \multicolumn{14}{|l|}{ Souvenirs } \\
\hline Agricultural products & 330.1 & 308.7 & 362.8 & 303.9 & 330.9 & 348.7 & 375.9 & 384.0 & 392.2 & 158.7 & 194.1 & 292.3 & 412.8 \\
\hline Agricultural processed products & 327.2 & 300.5 & 300.0 & 311.8 & 294.1 & 311.1 & 321.7 & 328.4 & 335.1 & 134.7 & 165.1 & 250.0 & 354.5 \\
\hline Marine products & 1161.6 & 1160.7 & 1098.4 & 872.7 & 968.4 & 1028.8 & 818.8 & 835.2 & 852.0 & 341.0 & 418.7 & 636.1 & 904.2 \\
\hline Fisheries processed products & 865.2 & 824.8 & 866.2 & 730.2 & 754.6 & 741.7 & 769.0 & 784.5 & 800.3 & 320.4 & 393.3 & 597.5 & 849.1 \\
\hline Confectionery & 5198.0 & 5197.2 & 5346.6 & 5010.8 & 5335.7 & 5459.9 & 5907.1 & 6148.7 & 6429.3 & 2317.1 & 2819.3 & 4226.1 & 6782.0 \\
\hline Other food items & 6017.8 & 6057.0 & 6294.5 & 5606.0 & 6614.7 & 6710.7 & 6691.3 & 7050.0 & 7477.0 & 2566.4 & 3105.4 & 4610.7 & 7858.8 \\
\hline Fiber products & 7328.3 & 6969.6 & 7005.0 & 6058.4 & 6387.8 & 7078.1 & 6458.7 & 6635.8 & 6832.0 & 2523.0 & 3076.4 & 4629.8 & 7195.4 \\
\hline Shoes, bags & 1595.7 & 1493.2 & 1980.4 & 1805.9 & 2391.4 & 2170.8 & 2159.5 & 2395.6 & 2689.5 & 686.4 & 802.6 & 1125.3 & 2785.4 \\
\hline Ceramics and glass products & 171.2 & 188.7 & 134.0 & 152.9 & 146.8 & 135.4 & 123.2 & 125.6 & 128.0 & 50.9 & 62.7 & 95.7 & 136.6 \\
\hline Publication & 356.4 & 366.8 & 380.4 & 322.2 & 364.1 & 366.6 & 346.4 & 368.6 & 395.7 & 123.1 & 147.3 & 214.7 & 411.7 \\
\hline Wood products and paper products & 252.2 & 236.1 & 185.5 & 160.4 & 196.4 & 179.9 & 233.3 & 238.3 & 243.4 & 98.3 & 120.3 & 181.4 & 256.4 \\
\hline Medical supplies and Cosmetics & 700.9 & 755.5 & 818.6 & 1077.1 & 1956.6 & 2238.7 & 2493.7 & 3048.5 & 3751.4 & 585.4 & 627.3 & 737.9 & 3852.7 \\
\hline Film & 75.4 & 90.3 & 68.0 & 36.6 & 51.4 & 52.8 & 43.6 & 44.4 & 45.1 & 16.7 & 20.4 & 30.9 & 47.5 \\
\hline Electrical equipment and related products & 893.8 & 737.0 & 667.6 & 847.2 & 889.2 & 739.0 & 806.4 & 918.0 & 1058.0 & 232.9 & 266.4 & 359.0 & 1090.1 \\
\hline Camera, glasses, watch & 642.2 & 580.9 & 669.2 & 641.8 & 798.8 & 647.6 & 748.4 & 827.4 & 925.7 & 234.8 & 274.7 & 386.2 & 959.1 \\
\hline Sports equipment $\cdot \mathrm{CD} \cdot$ stationery & 330.7 & 328.5 & 326.4 & 300.3 & 513.0 & 668.1 & 775.4 & 791.7 & 808.4 & 323.6 & 395.2 & 593.8 & 848.5 \\
\hline Other manufactured products & 477.0 & 461.0 & 463.5 & 514.0 & 575.3 & 661.0 & 650.3 & 722.2 & 811.5 & 221.6 & 261.3 & 371.2 & 845.5 \\
\hline \multicolumn{14}{|l|}{ Activities } \\
\hline A day spa warm-bathing facility beauty salon & 408.9 & 402.7 & 369.2 & 362.7 & 434.1 & 393.7 & 462.1 & 471.5 & 481.0 & 192.7 & 236.4 & 359.1 & 510.2 \\
\hline Museums, museums, zoos and gardens, aquariums & 315.7 & 342.7 & 330.7 & 321.7 & 368.4 & 388.7 & 409.3 & 432.7 & 460.7 & 157.5 & 190.7 & 283.3 & 485.2 \\
\hline Watching sports and art appreciation & 105.5 & 76.2 & 106.9 & 118.0 & 132.5 & 162.0 & 186.0 & 192.3 & 199.4 & 77.0 & 93.6 & 139.5 & 208.7 \\
\hline Amusement parks and expositions & 314.3 & 325.2 & 344.0 & 352.7 & 400.0 & 410.9 & 434.5 & 455.4 & 480.0 & 172.0 & 208.6 & 310.4 & 504.5 \\
\hline Sports facilities & 161.9 & 166.8 & 217.8 & 173.1 & 181.9 & 183.5 & 176.8 & 180.8 & 184.9 & 75.6 & 92.1 & 137.6 & 193.1 \\
\hline Ski lift fee & 62.9 & 85.2 & 70.7 & 71.1 & 68.9 & 50.3 & 65.6 & 67.0 & 68.3 & 27.4 & 33.6 & 51.0 & 72.5 \\
\hline Camp site & 1.1 & 1.2 & 1.3 & 7.2 & 1.1 & 2.0 & 1.1 & 1.1 & 1.1 & 0.5 & 0.6 & 0.8 & 1.2 \\
\hline Exhibition and convention participation fee & 17.0 & 14.6 & 13.8 & 16.2 & 12.7 & 19.4 & 19.5 & 20.0 & 20.4 & 8.3 & 10.1 & 15.2 & 21.4 \\
\hline Tourist farm & 58.9 & 68.0 & 54.7 & 61.4 & 69.2 & 61.8 & 72.1 & 73.7 & 75.3 & 30.6 & 37.4 & 56.1 & 78.9 \\
\hline Fishing boat & 60.4 & 44.7 & 39.2 & 25.5 & 36.8 & 39.3 & 48.1 & 49.1 & 50.2 & 20.2 & 24.8 & 37.4 & 52.9 \\
\hline Guide fee & 16.3 & 23.8 & 23.0 & 19.1 & 32.6 & 28.2 & 26.7 & 27.2 & 27.8 & 11.2 & 13.7 & 20.7 & 29.4 \\
\hline Rental charge & 34.2 & 41.9 & 32.8 & 38.6 & 55.0 & 51.6 & 76.0 & 79.2 & 83.0 & 27.1 & 32.8 & 48.6 & 86.8 \\
\hline Massage & 53.8 & 48.0 & 49.6 & 43.7 & 31.8 & 31.9 & 36.8 & 37.5 & 38.2 & 15.0 & 18.5 & 28.6 & 41.0 \\
\hline Photo shoot fee & 27.9 & 20.9 & 26.5 & 27.9 & 20.1 & 19.6 & 16.2 & 16.5 & 16.9 & 6.7 & 8.3 & 12.6 & 17.9 \\
\hline Mail and communication charges & 38.0 & 26.1 & 21.1 & 30.1 & 12.9 & 23.7 & 21.5 & 21.8 & 22.2 & 8.4 & 10.3 & 15.6 & 23.5 \\
\hline Home delivery & 1546.7 & 1471.9 & 1536.5 & 1498.2 & 1501.1 & 1296.2 & 1332.2 & 1355.2 & 1378.6 & 522.9 & 642.3 & 980.6 & 1466.5 \\
\hline Travel insurance Credit card admission fee & 37.0 & 38.2 & 35.3 & 25.1 & 27.0 & 43.3 & 41.3 & 41.7 & 42.1 & 11.5 & 13.5 & 18.9 & 42.0 \\
\hline Passport application fee & 35.6 & 39.1 & 35.9 & 35.5 & 31.1 & 34.8 & 33.7 & 33.8 & 33.9 & 5.3 & 5.4 & 5.5 & 31.2 \\
\hline
\end{tabular}


Table A3. Cont.

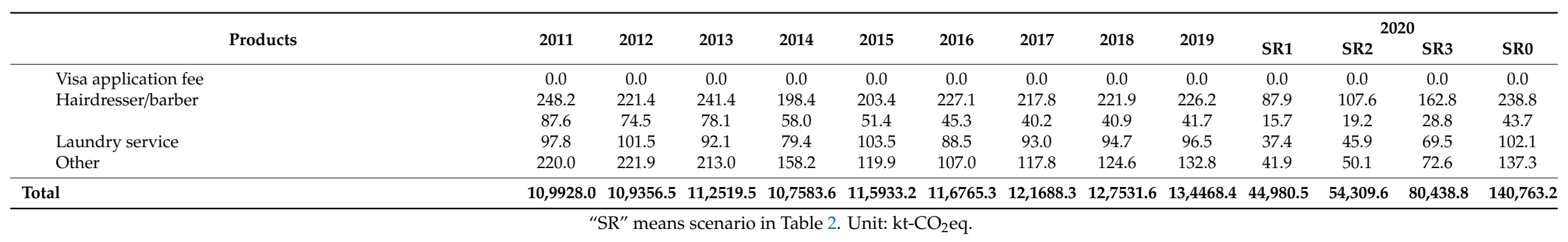

Table A4. Results of employment breakdown (2011-2020).

\begin{tabular}{|c|c|c|c|c|c|c|c|c|c|c|c|c|c|}
\hline \multirow{2}{*}{ Products } & \multirow{2}{*}{2011} & \multirow{2}{*}{2012} & \multirow{2}{*}{2013} & \multirow{2}{*}{2014} & \multirow{2}{*}{2015} & \multirow{2}{*}{2016} & \multirow{2}{*}{2017} & \multirow{2}{*}{2018} & \multirow{2}{*}{2019} & \multicolumn{4}{|c|}{2020} \\
\hline & & & & & & & & & & SR1 & SR2 & SR3 & SR0 \\
\hline \multicolumn{14}{|l|}{ Travel agencies, operators, and guides } \\
\hline Travel agencies, tour operators, and tourist guide services & 58.1 & 61.0 & 63.8 & 59.2 & 63.4 & 61.2 & 61.3 & 62.9 & 64.7 & 18.9 & 22.4 & 32.2 & 65.8 \\
\hline \multicolumn{14}{|l|}{ Transport } \\
\hline Airplane (domestic, local) & 109.6 & 108.8 & 110.0 & 112.5 & 122.1 & 116.4 & 120.0 & 122.6 & 125.3 & 48.1 & 59.1 & 90.6 & 134.0 \\
\hline Airplane (international flight) & 59.1 & 62.3 & 68.2 & 76.9 & 81.4 & 80.3 & 87.8 & 95.2 & 104.7 & 15.1 & 15.2 & 15.4 & 101.0 \\
\hline Bullet train & 107.2 & 115.3 & 120.1 & 121.9 & 145.5 & 153.2 & 144.7 & 152.1 & 160.8 & 56.0 & 67.9 & 101.3 & 169.5 \\
\hline Railways (excluding bullet train) & 46.4 & 43.8 & 47.4 & 40.7 & 46.2 & 47.2 & 44.9 & 45.8 & 46.7 & 18.4 & 22.5 & 34.0 & 49.2 \\
\hline Bus & 91.5 & 80.4 & 82.1 & 65.2 & 68.9 & 75.7 & 76.7 & 78.2 & 79.8 & 31.6 & 38.7 & 58.2 & 83.9 \\
\hline Taxi & 35.0 & 33.4 & 35.7 & 40.2 & 43.2 & 51.9 & 47.0 & 51.2 & 56.5 & 16.3 & 19.4 & 28.1 & 59.1 \\
\hline Ships (inner service, local) & 9.7 & 9.9 & 9.3 & 9.3 & 10.2 & 10.2 & 10.5 & 10.9 & 11.2 & 4.2 & 5.1 & 7.8 & 12.0 \\
\hline Ships (outbound) & 0.3 & 0.3 & 0.2 & 0.3 & 0.4 & 0.3 & 0.3 & 0.3 & 0.3 & 0.0 & 0.1 & 0.1 & 0.3 \\
\hline Car rental fee & 15.3 & 16.2 & 19.0 & 15.3 & 17.9 & 21.3 & 20.3 & 21.4 & 22.6 & 7.8 & 9.5 & 14.3 & 24.0 \\
\hline Gasoline cost & 56.3 & 55.3 & 55.3 & 51.0 & 48.7 & 47.1 & 51.3 & 52.3 & 53.4 & 21.4 & 26.2 & 39.6 & 56.4 \\
\hline Parking lot, toll road charge (except for highway charge) & 25.7 & 17.7 & 17.7 & 21.4 & 19.0 & 19.0 & 19.8 & 20.2 & 20.6 & 8.1 & 9.9 & 14.9 & 21.7 \\
\hline Highway charge & 44.9 & 51.3 & 54.2 & 50.2 & 57.4 & 60.6 & 65.7 & 67.1 & 68.4 & 27.3 & 33.5 & 50.7 & 72.4 \\
\hline \multicolumn{14}{|l|}{ Accommodation } \\
\hline Accommodation services & 539.6 & 570.9 & 596.2 & 561.4 & 667.8 & 704.9 & 743.1 & 798.3 & 865.8 & 266.3 & 321.8 & 479.4 & 919.4 \\
\hline Vacation home ownership (imputed) & 6.4 & 6.3 & 6.3 & 6.8 & 6.9 & 7.0 & 7.0 & 7.2 & 7.3 & 2.9 & 3.5 & 5.5 & 7.9 \\
\hline \multicolumn{14}{|l|}{ Food and beverage } \\
\hline Food and beverage serving services & 556.8 & 572.1 & 626.2 & 610.0 & 722.5 & 780.4 & 807.8 & 867.6 & 940.6 & 295.5 & 355.3 & 523.1 & 989.6 \\
\hline \multicolumn{14}{|l|}{ Souvenirs } \\
\hline Agricultural products & 10.3 & 9.6 & 11.3 & 9.5 & 10.3 & 10.8 & 11.7 & 11.9 & 12.2 & 4.9 & 6.0 & 9.1 & 12.8 \\
\hline Agricultural processed products & 13.1 & 12.1 & 12.1 & 12.5 & 11.8 & 12.5 & 12.9 & 13.2 & 13.5 & 5.4 & 6.6 & 10.0 & 14.2 \\
\hline
\end{tabular}


Table A4. Cont.

\begin{tabular}{|c|c|c|c|c|c|c|c|c|c|c|c|c|c|}
\hline \multirow{2}{*}{ Products } & \multirow{2}{*}{2011} & \multirow{2}{*}{2012} & \multirow{2}{*}{2013} & \multirow{2}{*}{2014} & \multirow{2}{*}{2015} & \multirow{2}{*}{2016} & \multirow{2}{*}{2017} & \multirow{2}{*}{2018} & \multirow{2}{*}{2019} & \multicolumn{4}{|c|}{2020} \\
\hline & & & & & & & & & & SR1 & SR2 & SR3 & SR0 \\
\hline Marine products & 34.8 & 34.8 & 32.9 & 26.1 & 29.0 & 30.8 & 24.5 & 25.0 & 25.5 & 10.2 & 12.5 & 19.1 & 27.1 \\
\hline Fisheries processed products & 21.9 & 20.9 & 22.0 & 18.5 & 19.1 & 18.8 & 19.5 & 19.9 & 20.3 & 8.1 & 10.0 & 15.2 & 21.5 \\
\hline Confectionery & 204.1 & 204.0 & 209.9 & 196.7 & 209.5 & 214.3 & 231.9 & 241.4 & 252.4 & 91.0 & 110.7 & 165.9 & 266.2 \\
\hline Other food items & 178.1 & 179.3 & 186.3 & 165.9 & 195.8 & 198.7 & 198.1 & 208.7 & 221.3 & 76.0 & 91.9 & 136.5 & 232.6 \\
\hline Fiber products & 161.5 & 153.6 & 154.4 & 133.5 & 140.8 & 156.0 & 142.3 & 146.3 & 150.6 & 55.6 & 67.8 & 102.0 & 158.6 \\
\hline Shoes, bags & 68.9 & 64.5 & 85.6 & 78.0 & 103.3 & 93.8 & 93.3 & 103.5 & 116.2 & 29.7 & 34.7 & 48.6 & 120.3 \\
\hline Ceramics and glass products & 10.4 & 11.5 & 8.1 & 9.3 & 8.9 & 8.2 & 7.5 & 7.6 & 7.8 & 3.1 & 3.8 & 5.8 & 8.3 \\
\hline Publication & 11.7 & 12.0 & 12.5 & 10.6 & 11.9 & 12.0 & 11.4 & 12.1 & 13.0 & 4.0 & 4.8 & 7.0 & 13.5 \\
\hline Wood products and paper products & 4.7 & 4.4 & 3.5 & 3.0 & 3.7 & 3.4 & 4.4 & 4.5 & 4.6 & 1.9 & 2.3 & 3.4 & 4.8 \\
\hline Medical supplies and cosmetics & 17.1 & 18.5 & 20.0 & 26.3 & 47.8 & 54.7 & 61.0 & 74.5 & 91.7 & 14.3 & 15.3 & 18.0 & 94.2 \\
\hline Film & 1.1 & 1.3 & 1.0 & 0.5 & 0.8 & 0.8 & 0.6 & 0.7 & 0.7 & 0.2 & 0.3 & 0.5 & 0.7 \\
\hline Electrical equipment and related products & 24.8 & 20.5 & 18.5 & 23.5 & 24.7 & 20.5 & 22.4 & 25.5 & 29.4 & 6.5 & 7.4 & 10.0 & 30.3 \\
\hline Camera, glasses, watch & 26.3 & 23.8 & 27.4 & 26.3 & 32.7 & 26.5 & 30.6 & 33.9 & 37.9 & 9.6 & 11.2 & 15.8 & 39.3 \\
\hline Sports equipment $\cdot \mathrm{CD} \cdot$ stationery & 13.5 & 13.4 & 13.4 & 12.3 & 21.0 & 27.3 & 31.7 & 32.4 & 33.1 & 13.2 & 16.2 & 24.3 & 34.7 \\
\hline Other manufactured products & 19.5 & 18.9 & 19.0 & 21.0 & 23.5 & 27.1 & 26.6 & 29.6 & 33.2 & 9.1 & 10.7 & 15.2 & 34.6 \\
\hline \multicolumn{14}{|l|}{ Activities } \\
\hline A day spa warm-bathing facility beauty salon & 18.1 & 17.8 & 16.3 & 16.1 & 19.2 & 17.4 & 20.5 & 20.9 & 21.3 & 8.5 & 10.5 & 15.9 & 22.6 \\
\hline Museums, museums, zoos and gardens, aquariums & 21.4 & 23.2 & 22.4 & 21.8 & 24.9 & 26.3 & 27.7 & 29.3 & 31.2 & 10.7 & 12.9 & 19.2 & 32.8 \\
\hline Watching sports and art appreciation & 10.3 & 7.5 & 10.5 & 11.6 & 13.0 & 15.9 & 18.2 & 18.8 & 19.5 & 7.5 & 9.2 & 13.7 & 20.5 \\
\hline Amusement parks and expositions & 30.8 & 31.9 & 33.7 & 34.6 & 39.2 & 40.3 & 42.6 & 44.6 & 47.0 & 16.9 & 20.4 & 30.4 & 49.4 \\
\hline Sports Facilities & 18.5 & 19.1 & 24.9 & 19.8 & 20.8 & 21.0 & 20.2 & 20.7 & 21.2 & 8.7 & 10.5 & 15.7 & 22.1 \\
\hline Ski lift fee & 2.4 & 3.2 & 2.6 & 2.7 & 2.6 & 1.9 & 2.5 & 2.5 & 2.6 & 1.0 & 1.3 & 1.9 & 2.7 \\
\hline Camp site & 0.1 & 0.1 & 0.2 & 0.8 & 0.1 & 0.2 & 0.1 & 0.1 & 0.1 & 0.1 & 0.1 & 0.1 & 0.1 \\
\hline Exhibition and convention participation fee & 2.9 & 2.4 & 2.3 & 2.7 & 2.1 & 3.2 & 3.3 & 3.3 & 3.4 & 1.4 & 1.7 & 2.5 & 3.6 \\
\hline Tourist farm & 1.6 & 1.9 & 1.5 & 1.7 & 1.9 & 1.7 & 2.0 & 2.1 & 2.1 & 0.9 & 1.0 & 1.6 & 2.2 \\
\hline Fishing boat & 6.2 & 4.6 & 4.0 & 2.6 & 3.8 & 4.0 & 4.9 & 5.0 & 5.1 & 2.1 & 2.5 & 3.8 & 5.4 \\
\hline Guide fee & 2.0 & 2.9 & 2.9 & 2.4 & 4.0 & 3.5 & 3.3 & 3.4 & 3.4 & 1.4 & 1.7 & 2.6 & 3.6 \\
\hline Rental charge & 2.8 & 3.4 & 2.7 & 3.2 & 4.5 & 4.2 & 6.2 & 6.5 & 6.8 & 2.2 & 2.7 & 4.0 & 7.1 \\
\hline Massage & 7.8 & 7.0 & 7.2 & 6.3 & 4.6 & 4.6 & 5.3 & 5.4 & 5.5 & 2.2 & 2.7 & 4.1 & 5.9 \\
\hline Photo shoot fee & 3.6 & 2.7 & 3.4 & 3.6 & 2.6 & 2.5 & 2.1 & 2.1 & 2.2 & 0.9 & 1.1 & 1.6 & 2.3 \\
\hline Mail and communication charges & 5.2 & 3.6 & 2.9 & 4.1 & 1.8 & 3.3 & 2.9 & 3.0 & 3.0 & 1.2 & 1.4 & 2.1 & 3.2 \\
\hline Home delivery & 17.8 & 17.0 & 17.7 & 17.3 & 17.3 & 15.0 & 15.4 & 15.6 & 15.9 & 6.0 & 7.4 & 11.3 & 16.9 \\
\hline Travel insurance Credit card admission fee & 5.3 & 5.5 & 5.1 & 3.6 & 3.9 & 6.2 & 5.9 & 6.0 & 6.1 & 1.7 & 1.9 & 2.7 & 6.0 \\
\hline Passport application fee & 3.4 & 3.7 & 3.4 & 3.4 & 3.0 & 3.3 & 3.2 & 3.2 & 3.2 & 0.5 & 0.5 & 0.5 & 3.0 \\
\hline Visa application fee & 0.0 & 0.0 & 0.0 & 0.0 & 0.0 & 0.0 & 0.0 & 0.0 & 0.0 & 0.0 & 0.0 & 0.0 & 0.0 \\
\hline Hairdresser/Barber & 36.1 & 32.2 & 35.1 & 28.8 & 29.6 & 33.0 & 31.6 & 32.2 & 32.9 & 12.8 & 15.6 & 23.6 & 34.7 \\
\hline Develop and print photos & 10.9 & 9.2 & 9.7 & 7.2 & 6.4 & 5.6 & 5.0 & 5.1 & 5.2 & 1.9 & 2.4 & 3.6 & 5.4 \\
\hline Laundry service & 9.1 & 9.4 & 8.6 & 7.4 & 9.6 & 8.2 & 8.6 & 8.8 & 9.0 & 3.5 & 4.3 & 6.5 & 9.5 \\
\hline Other & 27.2 & 27.5 & 26.4 & 19.6 & 14.8 & 13.2 & 14.6 & 15.4 & 16.4 & 5.2 & 6.2 & 9.0 & 17.0 \\
\hline Total & 2827.4 & 2843.7 & 2993.0 & 2837.2 & 3245.9 & 3387.5 & 3485.0 & 3698.0 & 3955.2 & 1277.7 & 1540.5 & 2278.2 & 4156.1 \\
\hline
\end{tabular}




\section{References}

1. United Nations Framework Convention on Climate Change (UNFCCC). The Paris Agreement. Available online: https:/unfccc.int/process-and-meetings/the-paris-agreement/the-paris-agreement (accessed on 27 October 2020).

2. United Nations Environment Programme. Emissions Gap Report 2019; UNEP: Nairobi, Kenya, 2019; Available online: https://www.unenvironment.org/resources/emissions-gap-report-2019 (accessed on 27 October 2020).

3. Ministry of the Environment Government of Japan. Submission of Japan's Nationally Determined Contribution (NDC). Available online: https://www.env.go.jp/press/files/jp/113675.pdf (accessed on 27 October 2020).

4. The Long-Term Strategy under the Paris Agreement; The Government of Japan: Tokyo, Japan. Available online: https://www.env.go.jp/press/111913.pdf (accessed on 27 October 2020).

5. Prime Minister Suga's Statement of Belief at the 203rd Diet Session; The Government of Japan: Tokyo, Japan. Available online: https://www.kantei.go.jp/jp/99_suga/statement/2020/1026shoshinhyomei.html (accessed on 27 October 2020).

6. The World Health Organization (WHO). COVID-19 Response Fund. Available online: https://www.who.int/ emergencies/diseases/novel-coronavirus-2019/donate (accessed on 27 October 2020).

7. The World Health Organization (WHO). Coronavirus Disease 2019. Available online: https://www.who.int/ emergencies/diseases/novel-coronavirus-2019 (accessed on 27 October 2020).

8. Ministry of Health, Labour and Welfare. About New Coronavirus Infection. Available online: https://www. mhlw.go.jp/stf/seisakunitsuite/bunya/0000164708_00001.html\#kokunaihassei (accessed on 27 October 2020).

9. Cabinet Public Relations Office, Cabinet Secretariat. New Coronavirus Infectious Disease Control Headquarters. Available online: https://www.kantei.go.jp/jp/98_abe/actions/202005/04corona.html (accessed on 27 October 2020).

10. New Coronavirus Infectious Disease Control Headquarters. Basic Countermeasure Policy for New Coronavirus Infection Control. Available online: https://corona.go.jp/expert-meeting/pdf/kihon_h_0504.pdf (accessed on 27 October 2020).

11. Kuniya, T. Prediction of the Epidemic Peak of Coronavirus Disease in Japan, 2020. J. Clin. Med. 2020, 9, 789. [CrossRef] [PubMed]

12. The International Monetary Fund (IMF). World Economic Outlook, April 2020: The Great Lockdown. Available online: https://www.imf.org/en/Publications/WEO/Issues/2020/04/14/weo-april-2020 (accessed on 27 October 2020).

13. The World Tourism Organization (UNWTO). COVID-19: Putting People First. Available online: https: //www.unwto.org/tourism-covid-19 (accessed on 27 October 2020).

14. Japan National Tourism Organization (JNTO). Collection and Announcement of Foreign Visitor Statistics. Available online: https://www.jnto.go.jp/jpn/statistics/data_info_listing/pdf/200415_monthly.pdf (accessed on 27 October 2020).

15. The Japan Tourism Agency (JTA). Survey on Consumption Trends for Foreigners Visiting Japan. Available online: https://www.mlit.go.jp/kankocho/siryou/toukei/content/001340596.pdf (accessed on 27 October 2020).

16. The Japan Tourism Agency (JTA). Survey of Overnight Travel Statistics. Available online: https://www.mlit. go.jp/kankocho/content/001342343.pdf (accessed on 27 October 2020).

17. The World Tourism Organization (UNWTO). Impact Assessment of the COVID-19 Outbreak on International Tourism (Updated May 2020). Available online: https://www.unwto.org/impact-assessment-of-the-covid-19outbreak-on-international-tourism (accessed on 27 October 2020).

18. Nicola, M.; Alsafi, Z.; Sohrabi, C.; Kerwan, A.; Al-Jabir, A.; Iosifidis, C.; Agha, M.; Agha, R. The socio-economic implications of the coronavirus pandemic (COVID-19): A review. Int. J. Surg. 2020, 78, 185-193. [CrossRef] [PubMed]

19. Mariolis, T.; Rodousakis, N.; Soklis, G. The COVID-19 Multiplier Effects of Tourism on the Greek Economy. Tour. Econ. 2020. [CrossRef]

20. Sun, X.; Wandelt, S.; Zhang, A. How did COVID-19 impact air transportation? A first peek through the lens of complex networks. J. Air Trans. Manag. 2020, 89, 101928. [CrossRef] [PubMed] 
21. Chang, C.-L.; McAleer, M.; Ramos, V. A Charter for Sustainable Tourism after COVID-19. Sustainability 2020, 12, 3671. [CrossRef]

22. Lenzen, M.; Sun, Y.; Faturay, F.; Ting, Y.; Geschke, A.; Malik, A. The carbon footprint of global tourism. Nat. Clim. Chang. 2018, 8, 522-528. [CrossRef]

23. Rosenblum, J.; Horvath, A.; Hendrickson, C. Environmental implications of service industries. Environ. Sci. Technol. 2000, 34, 4669-4676. [CrossRef]

24. Patterson, M.G.; McDonald, G. How Clean and Green Is New Zealand Tourism? Lifecycle and Future Environmental Impacts; Manaaki Whenua Press: Lincoln, New Zealand, 2004.

25. Berners-Lee, M.; Howard, D.C.; Moss, J.; Kaivanto, K.; Scott, W.A. Greenhouse gas footprinting for small businesses-The use of input-output data. Sci. Total Environ. 2011, 409, 883-891. [CrossRef] [PubMed]

26. Scheepens, A.E.; Vogtländer, J.G.; Brezet, J.C. Two life cycle assessment (LCA) based methods to analyse and design complex (regional) circular economy systems. Case: Making water tourism more sustainable. J. Clean. Prod. 2016, 114, 257-268. [CrossRef]

27. Cadarso, M.-Á.; Gómez, N.; López, L.-A.; Tobarra, M.-Á.; Zafrilla, J.-E. Quantifying Spanish tourism's carbon footprint: The contributions of residents and visitors: A longitudinal study. J. Sustain. Tour. 2015, 23, 922-946. [CrossRef]

28. Qin, Y.; Li, X.; Rong, P. Urban tourism carbon accounting based on improved EIO-LCA model: A case study of Kaifeng City in Henan Province. Prog. Geogr. 2015, 34, 132-140.

29. Kitamura, Y.; Ichisugi, Y.; Karkour, S.; Itsubo, N. Carbon Footprint Evaluation Based on Tourist Consumption toward Sustainable Tourism in Japan. Sustainability 2020, 12, 2219. [CrossRef]

30. Isaifan, R.J. The dramatic impact of Coronavirus outbreak on air quality: Has it saved as much as it has killed so far? Global J. Environ. Sci. Manag. 2020, 6, 275-288. [CrossRef]

31. Cooper, J.A.; Alderman, D.H. Cancelling March Madness exposes opportunities for a more sustainable sports tourism economy. Tour. Geogr. 2020. [CrossRef]

32. Sun, Y.; Higham, J. Overcoming information asymmetry in tourism carbon management: The application of a new reporting architecture to Aotearoa New Zealand. Tour. Manag. 2020, 83, 104231. [CrossRef] [PubMed]

33. The Japan Tourism Agency (JTA). Economic Ripple Effect. Available online: https://www.mlit.go.jp/kankocho/ siryou/toukei/kouka.html (accessed on 27 October 2020).

34. Japan Tourism Agency (JTA). Research Study on Economic Impacts of Tourism in Japan (2017 Edition). 2019. Available online: http://www.mlit.go.jp/kankocho/siryou/toukei/shouhidoukou.html\#cp3 (accessed on 27 October 2020).

35. Internal Revenue Service (IRS). Yearly Average Currency Exchange Rates. Available online: https:// www.irs.gov/individuals/international-taxpayers/yearly-average-currency-exchange-rates (accessed on 27 October 2020).

36. Japan National Tourism Organization (JNTO). Collection and Announcement of Foreign Visitor Statistics for 2020. Available online: https://www.jnto.go.jp/jpn/statistics/data_info_listing/index.html (accessed on 14 October 2020).

37. The Japan Tourism Agency (JTA). Travel/Tourism Consumption Trend Survey. Available online: https: //www.mlit.go.jp/kankocho/siryou/toukei/shouhidoukou.html (accessed on 14 October 2020).

38. Leontief, W.W. Input-Output Economics, 2nd ed.; Oxford University Press: New York, NY, USA, 1986.

39. Tahara, K. Development of Inventory Database for Environmental Hotspot Analysis using IDEA. J. Life Cycle Assess. Jpn. 2019, 15, 22-32. [CrossRef]

40. Kondo, Y. Estimation of 2011 Waste Input-output Table for Japan. J. Life Cycle Assess. Jpn. 2019, 15, 33-41. [CrossRef]

41. Ichisugi, Y.; Suguri, S.; Suzuki, H.; Fuji, C.; Tahara, K.; Kondo, Y.; Itsubo, N. Development and Application of Hotspots Analysis Method Considering Environmental Aspects and Social Aspects. In Proceedings of the 12th Meeting of the Institute of Life Cycle Assessment, Tsukuba, Japan, 1-3 March 2017; pp. 214-215.

42. Foreign Policy. The Tourism Industry Is in Trouble. These Countries Will Suffer the Most. Available online: https:/foreignpolicy.com/2020/04/01/coronavirus-tourism-industry-worst-hit-countriesinfographic/ (accessed on 27 October 2020).

43. Japan Tourism Agency. The Japan Tourism White Paper (2017). (Announcement 12 June 2019). Available online: http://www.mlit.go.jp/common/001237338.pdf (accessed on 28 October 2020). 
44. Ministry of Land, Infrastructure and Transport. Outline of Supplementary Budget Related to the Ministry of Land, Infrastructure, Transport and Tourism in FY 2020. Available online: https://www.mlit.go.jp/report/ press/content/001339698.pdf (accessed on 27 October 2020).

45. Japan Tourism Agency. About the Usage Record in the Go to Travel Business (22 July to 15 September). Available online: https://www.mlit.go.jp/kankocho/topics06_000279.html (accessed on 28 October 2020).

46. Institute for Global Environmental Strategies (IGES). Implications of COVID-19 for the Environment and Sustainability. Available online: https://www.iges.or.jp/en/publication_documents/pub/policysubmission/en/ 10841/\%231+COVID-19+Position+Paper+Final+\%28EN\%29.pdf (accessed on 27 October 2020).

47. Society of Environmental Toxicology and Chemistry (SETAC). SETAC Europe 30th Annual Meeting Sustainability Initiatives. Available online: https://scicon.setac.org/\#topics-tab (accessed on 27 October 2020).

48. International Labour Organization (ILO). The Impact of COVID-19 on the Tourism Sector. Available online: https://www.ilo.org/sector/Resources/publications/WCMS_741468/lang--en/index.htm (accessed on 27 October 2020).

49. Ministry of Internal Affairs and Communications (MIC). Labor Force Survey. Available online: https: //www.stat.go.jp/data/roudou/sokuhou/tsuki/index.html (accessed on 27 October 2020).

50. Japan Association of Travel Agents (JATA). Travel Industry 2018. Available online: https://www.jata-net.or. jp/data/stats/2018/pdf/2018_sujryoko.pdf (accessed on 27 October 2020).

51. ANA Holdings Inc. ANA Holdings Financial Results for the Six Months Ended 30 September 2020. Available online: https://www.anahd.co.jp/group/en/pr/202010/20201027.html (accessed on 27 October 2020).

52. Japan Airlines. Financial Results Announcement (3 August 2020). Available online: http://www.jal.com/cms/ en/2020-08-03-financial-results-announcement--august-3--2020-.html (accessed on 27 October 2020).

Publisher's Note: MDPI stays neutral with regard to jurisdictional claims in published maps and institutional affiliations. 